Check for updates

Cite this: RSC Adv., 2019, 9, 23508

\title{
A bio-inspired strategy for the synthesis of zinc oxide nanoparticles (ZnO NPs) using the cell extract of cyanobacterium Nostoc sp. EA03: from biological function to toxicity evaluation
}

Mojgan Ebadi, ${ }^{a}$ Mohammad Reza Zolfaghari, ${ }^{a}$ Seyyed Soheil Aghaei, ${ }^{a}$ Mohsen Zargar, ${ }^{a}$ Morvarid Shafiei, ${ }^{b}$ Hossein Shahbani Zahiric and Kambiz Akbari Noghabi (D) *c

Cyanobacteria, as one of the largest groups of phototrophic bacteria, have a high potential as an excellent source of fine chemicals and bioactive compounds, including lipid-like compounds, amino acid derivatives, proteins, and pigments. This study aimed to synthesize $\mathrm{ZnO}$ nanoparticles using the cell extract of the cyanobacterium Nostoc sp. EA03 (CEN-ZnO NPs) through a rapid and eco-friendly approach. The biosynthesized nanoparticles, CEN-ZnO NPs, were characterized by UV-Vis spectroscopy, X-ray diffraction (XRD), zeta potential measurement, differential scanning calorimetry (DSC)/thermogravimetric analysis (TGA), FTIR, SEM, TEM, and EDX spectroscopy. The UV-Vis spectrum showed an absorption peak at $370 \mathrm{~nm}$. The star-shaped CEN-ZnO NPs, as observed in the TEM and SEM images, had an average diameter of 50-80 nm. MIC and MBC values for E. coli, P. aeruginosa and S. aureus, were determined to be, respectively, 2000, 2000, and $64 \mu \mathrm{g} \mathrm{ml}^{-1}$, and 2500, 2500 and $128 \mu \mathrm{g} \mathrm{ml}^{-1}$. Further analysis through confocal laser scanning microscopy (CLSM) provided the observable confirmation that the CEN-ZnO NPs stunted the bacterial growth, preventing the formation of exopolysaccharides. The AFM analysis of surface topography of bacterial biofilm samples treated with CEN-ZnO NPs showed a rugged topography in some parts of the biofilm surface, indicating the destruction of biofilms. In contrast, in the untreated control samples, the structured biofilms were flat and prominent. MTT assay indicated that CEN-ZnO NPs had less cytotoxicity on the MRC-5 lung fibroblast cells compared with the cancerous treated A549 cells. As the concentration of the CEN-ZnO NPs increased, the amount of ROS produced in the tested bacterial strains also increased. Analyzing the data obtained from flow cytometry showed that the higher concentrations of CEN-ZnO NPs lead to a reduction in the viability of $P$. aeruginosa PAO1, E. coli and S. aureus. The biosynthesized $\mathrm{ZnO}$ nanoparticles using Nostoc cell extracts exhibited different attributes, inspiring enough to be considered for further investigation.

Received 25th May 2019

Accepted 17th July 2019

DOI: $10.1039 / c 9 r a 03962 g$

rsc.li/rsc-advances

\section{Introduction}

Nanoparticles (NPs) are particles with one dimension ranging from 1 to 100 nanometers. They exhibit an enhanced catalytic reactivity, thermal conductivity, non-linear optical performance, and chemical steadiness owing to their large surface area to volume ratio. ${ }^{1}$ Nano materials are known as the miracles of modern medicine. ${ }^{2}$ Metallic nanoparticles have different physical and chemical properties due to their wide surface ratio, while their bulk forms may not have these features. ${ }^{3}$ The synthesis of nanoparticles (NPs) using plant

\footnotetext{
${ }^{a}$ Department of Microbiology, Islamic Azad University, Qom Branch, Qom, Iran ${ }^{b}$ Microbiology Research Center (MRC), Pasteur Institute of Iran, Tehran, Iran ${ }^{c}$ Department of Energy \& Environmental Biotechnology, National Institute of Genetic Engineering and Biotechnology (NIGEB), P. O. Box 14155-6343, Tehran, Iran. E-mail: Akbari@nigeb.ac.ir; Fax: +98-21-44787399; Tel: +98-21-44787352
}

extracts, bacteria, fungi, algae, etc., recognized as green technology, is the biocompatible, cost-effective and safe approach. ${ }^{4}$ The use of green and eco-friendly approaches for the synthesis of NPs has allowed them to develop for use in food, space, consumer healthcare, and the cosmetic industry. It has also vastly improved our understanding of their role in the control of disease and healthcare-associated infections in recent years. ${ }^{5}$ Various types of inorganic metal oxides have been synthesized and used in recent studies like $\mathrm{TiO}_{2}, \mathrm{CuO}$, and ZnO. Of all these metal oxides, ZnO NPs is of greatest interest, because their production is not expensive and easy to prepare safely. Zinc oxide ( $\mathrm{ZnO})$ is an n-type semiconducting metal oxide and has attracted significant attention in the past three years due to its wide range of applicability in the field of electronics, optics, and biomedical systems. US FDA has enlisted ZnO as GRAS (generally recognized as safe) metal oxide..$^{6,7}$ 
The presence of bioactive compounds in plants, algae, and microorganisms has made them a good candidate for the synthesis of nanoparticles (NPs). ${ }^{8}$ Cyanobacteria as a group of ancient and abundant microorganisms with prokaryotic cell structures have the capability of carbon dioxide-dependent photosynthesis. ${ }^{9}$ Among microorganisms, cyanobacteria are of great interest in NP synthesis, as they are a potential source of novel metabolites that have great importance from a biotechnological and industrial point of view. ${ }^{9}$ It has shown that they can utilize as a good source with biological features for the synthesis of gold $(\mathrm{Au})$, silver $(\mathrm{Ag})$, platinum $(\mathrm{Pt})$, and palladium (Pd) nanoparticles. ${ }^{10}$ The genus Nostoc is a valuable source of a wide spectrum of secondary metabolites, such as antioxidant enzymes, phycobiliproteins, vitamins, and phenolic compounds that have many uses as anticancer, anti-HIV, antimalarial, antifungal, and/or antimicrobial drugs ${ }^{11-13}$. Nostoc cell extract with a rich source of materials such as amino functional group, carboxyl, and hydroxyl, can be used as a metal oxide reducing and capping agents for NPs biosynthesis. ${ }^{14}$ Here, the green synthesis of zinc oxide nanoparticles was achieved using the cell extract of an indigenous cyanobacterial strain, Nostoc sp. EA03, in the first study of its kind. In this regard, the present study attempted to address the issues listed below: (1) isolation and characterization of a local cyanobacterial strain, (2) preparation of the cell extracts of selected cyanobacterial strain, Nostoc sp. EA03, (3) synthesis of ZnO NPs using the cell extract of Nostoc sp. EA03, (4) characterization of the CEN-ZnO NPs, (5) assessment of the antibacterial, anti-biofilm and antifungal activities of different concentrations of CEN-ZnO NPs against three important clinical bacterial isolates including $E$. coli 25922, P. aeruginosa $\mathrm{PAO1}$, and $S$. aureus 25923, (6) in vitro analysis of cytotoxic effect of CEN-ZnO NPs on human lung fibroblast cells MRC-5 and the cancerous human lung alveolar epithelial cells A549, (7) the measurement of reactive oxygen species (ROS) levels in tested bacterial cells after exposure to different concentrations of CEN-ZnO.

\section{Materials and methods}

\subsection{Materials and strains}

Zinc acetate dehydrate $\left(\geq 98 \% \mathrm{Zn}\left(\mathrm{CH}_{3} \mathrm{COO}\right)_{2} \cdot 2 \mathrm{H}_{2} \mathrm{O}\right)$ and sodium hydroxide $(\geq 98 \% \mathrm{NaOH})$ were purchased from SigmaAldrich, Australia. The clinical bacterial strains including $E$. coli ATCC 25922, P. aeruginosa PAO1, and S. aureus ATCC 25923 have received donations from Pasteur Institute of Iran.

\subsection{Sampling, isolation, and molecular identification of cyanobacterial strain}

To isolate the cyanobacterial strain, sampling was carried out independently from the aquatic environments including lakes, rivers in Alborz province (Iran). The samples were quickly transferred to the laboratory in suitable conditions. Detail regarding isolation and identification of the cyanobacterial strain was performed as described earlier. ${ }^{15-18}$

\subsection{Biomass collection}

The selected cyanobacterial strain was grown in laboratory condition in $2000 \mathrm{ml}$ Erlenmeyer flasks containing $400 \mathrm{ml}$ BG11 medium and stirred daily, with continuous illumination (a light intensity of 2000-3000 $1 \times$ ), at a temperature of $28{ }^{\circ} \mathrm{C}$ and $65 \%$ humidity for 10-12 days to collect the bacterial biomass. The cyanobacterial cells were collected in the late logarithmic phase by centrifugation at $5000 \mathrm{rpm} / 15 \mathrm{~min}$ and then washed two times with deionized water until all the medium debris removed. The collected biomass was used to obtain the cell extracts.

\subsection{Preparation of cyanobacterial cell extracts}

The biomass was collected and dried in the oven at $45{ }^{\circ} \mathrm{C}$ (to reach a constant weight) for 12 hours. In the next step, the dried biomass was crushed by a sterile mortar until it was smooth and uniform. The biomass powder was stored in a vial at $4{ }^{\circ} \mathrm{C}$ for further use. To obtain the cell extract, $1 \mathrm{~g}$ of dried biomass was dissolved in $50 \mathrm{ml}$ of deionized water using a stirrer at $60{ }^{\circ} \mathrm{C}$ for 15 min. The solution was filtered through Whatman no. 41 filter paper and the bacterial cell extract was obtained. The cell extract was kept at $4^{\circ} \mathrm{C}$ for the subsequent steps.

\subsection{Gas chromatography-mass spectroscopy (GC-MS) analysis}

The GC-MS analysis of the cyanobacterial cell extract was performed using a Scion 436-GC Bruker system and Gas chromatograph interfaced to a mass spectrometer (GC-MS) equipped with a BR-5MS (5\% diphenyl/95\% dimethyl polysiloxane) column, $30 \mathrm{~m} \times 0.25 \mathrm{~mm}$ ID $\times 0.25 \mu \mathrm{m}$ df. The defined conditions for GC-MS detection was carried out as described earlier. ${ }^{19}$

\subsection{Synthesis of CEN-ZnO NPs and optimization}

For the synthesis of CEN-ZnO NPs, $1000 \mu \mathrm{l}$ of cell extract was added drop by drop to $50 \mathrm{ml}$ zinc acetate dehydrate $\left(\mathrm{Zn}\left(\mathrm{CH}_{3}\right.\right.$ $\left.\mathrm{COO})_{2} \cdot 2 \mathrm{H}_{2} \mathrm{O}, 0.02 \mathrm{M}\right)$ through constant stirring using a magnetic stirrer. After $10 \mathrm{~min}$ of stirring, $0.1 \mathrm{M} \mathrm{NaOH}$ was added drop-wise to the constantly stirred solution until a faded white solution appeared (the color of the reaction mixture changes from green to white). The resultant faded white solution was maintained under vigorous stirring for $2 \mathrm{~h}$ followed by centrifugation at $5000 \mathrm{rpm} / 15 \mathrm{~min}$. The pellets were then washed with Milli-Q water three times and dried in a vacuum oven at $60{ }^{\circ} \mathrm{C}$ for $12 \mathrm{~h}$. To optimize the synthesis of CEN-ZnO NPs, a set of experiments was designed at different $\mathrm{pH}$ ranges and different concentrations of cell extract, separately. The $\mathrm{pH}$ of the reaction mixture was adjusted in the range of 7-9 by adding $0.1 \mathrm{M} \mathrm{NaOH}$, and different concentrations of the cell extract (1000-3000 $\mu \mathrm{l})$ were used in the reaction mixture. The dried powder material was kept in an airtight microtube at room temperature for subsequent analysis.

\subsection{Characterization of the synthesized CEN-ZnO NPs}

2.7.1. UV-visible (UV-Vis) spectroscopy analysis. The surface plasmon resonance of the resultant CEN-ZnO NPs were 
analyzed using a double-beam $\mathrm{T}^{+} 0^{+} \mathrm{UV}$-Vis spectrophotometer (Germany) with a wavelength range of 200-700 $\mathrm{nm}$.

2.7.2. X-ray powder diffraction (XRD) analysis. The XRD pattern of biosynthesized CEN-ZnO NPs was developed by XRD 3003 PTS, SEIFERT (Germany) in the range of $20^{\circ} \leq 2 \theta \leq 80^{\circ}$ at $40 \mathrm{kV}$ with $\mathrm{CuK} \alpha$ radiation $(k=1.54 \AA)$, and the crystalline domain diameter of ZnO NPs was calculated from the XRD peaks by the Debye-Scherrer equation $D=0.9 \lambda / \beta \cos \theta$. Here, $D$ is the crystalline domain diameter of $\mathrm{ZnO} \mathrm{NPs}, \lambda$ is the wavelength of the X-ray source used (1.541 $\AA$ ), and $B$ is the full width at half maximum of the diffraction peak.

2.7.3. Scanning electron microscopy (SEM) and energydispersive X-ray spectroscopy (EDX) analysis. Scanning electron microscopy (SEM) (TESCAN, VEGA3) was used to image and evaluate the morphology and size of the CEN-ZnO NPs. The CEN-ZnO NPs powder was used for SEM at an accelerating voltage of $20 \mathrm{kV}$. The scientific instrument Sirius SD model (the EDX spectrometer-equipped SEM) was used to determine the elemental analysis of the CEN-ZnO NPs.

2.7.4. Transmission electron microscopy (TEM) analysis. TEM images have obtained with a Philips CM300 (Netherland) instrument at an accelerating voltage of $100 \mathrm{kV}$. The preparation of the samples performed by dropping $20 \mu \mathrm{l}$ of CEN-ZnO NPs on a copper grid (200 mesh), dried at room temperature.

2.7.5. Fourier transform spectroscopy (FTIR) analysis. The chemical structures of ZnO, CEN-ZnO NPs, and cyanobacterial cell extract have studied by FTIR examination. The ZnO, CENZnO NPs and cell extract was finely ground and dispersed in pellets of $\mathrm{KBr}$ (Sigma) before performing the FTIR analysis. The FTIR spectrum was recorded in $3500-500 \mathrm{~cm}^{-1}$ region on an FTIR system (PerkinElmer, US). The wave number precision and resolution of the spectrum were $0.01 \mathrm{~cm}^{-1}$ and 4 , respectively.

2.7.6. Zeta potential. The zeta potential of the biosynthesized NPs was determined using the zeta potential analyzer Zetasizer Nano ZSP (ZSP instrument (Malvern), UK). For this purpose, $1 \mathrm{mg}$ of CEN-ZnO NPs powder was added to $1 \mathrm{ml}$ of deionized water and then placed in an ultrasonic bath for 10 minutes. The zeta potential was attained from the electrophoretic mobility using the Smoluchowski equation.

\subsection{Evaluation of antibacterial activity of biosynthesized CEN-ZnO NPs (MIC and MBC values)}

Three clinical bacterial strains were cultivated in Blood agar and Mueller-Hinton broth (MHB) and stored at $-70{ }^{\circ} \mathrm{C}$ in $30 \%$ glycerol. The MIC values were evaluated by the broth microdilution method as recommended by CLSI. ${ }^{20}$ The MIC of CENZnO NPs was determined against Gram-positive ( $S$. aureus ATCC 25923) and Gram-negative bacteria (P. aeruginosa PAO1 and $E$. coli 25922) by 96-well microtiter assay. Briefly, $100 \mu \mathrm{l}$ of Mueller-Hinton broth with CEN-ZnO NPs at different concentrations (i.e., 4, 8, 16, 32, 64, 128, 256, 512, 1000, and $2500 \mu \mathrm{g}$ $\left.\mathrm{ml}^{-1}\right)$ was added. Then, $5 \mu \mathrm{l}$ of microbial suspension $\left(1 \times 10^{8}\right.$ $\mathrm{CFU} \mathrm{ml} \mathrm{m}^{-1}$ ) was added to each well. The plates were incubated at $37{ }^{\circ} \mathrm{C}$ for $24 \mathrm{~h}$. Positive and negative controls were included as well. Following incubation, the MIC values were listed for each bacterial strain. The minimum concentration of samples that showed no visible growth was defined as MIC. Aliquots of $100 \mu \mathrm{l}$ from all tubes with no visible bacterial growth were seeded on MHA plates without CEN-ZnO NPs. The lowest concentration of samples that killed all the initial bacterial inoculum was defined as MBC.

\subsection{Biofilm formation}

In this experiment, a flat-bottomed 96-well cell culture microtiter plate was used. Bacterial inoculum concentrations were used to form biofilm by $P$. aeruginosa PAO1, E. coli 25922, and $S$. aureus 25923. Using 24 hours bacterial culture, the suspension was adjusted to McFarland standard $0.5\left(1 \times 10^{8} \mathrm{CFU} \mathrm{ml}^{-1}\right)$ in TSB supplemented with $0.2 \%$ glucose. Hundred microliters of each suspension were inoculated into each well. The test was performed using two replicates for each inoculum concentration. The microplates were incubated at $37{ }^{\circ} \mathrm{C}$ for $20 \mathrm{~h}$.

2.9.1. Determination of minimum biofilm inhibitory concentrations (MBIC) of CEN-ZnO NPs. The wells were filled with the medium as mentioned above. Two-fold CEN-ZnO NP serial dilutions were made in wells in a way that seven different concentrations were tested. The last row of each microtiter plate was used as controls. Using $24 \mathrm{~h}$ P. aeruginosa PAO1, E. coli 25922, and $S$. aureus 25923 cultures, the suspension was adjusted to McFarland standard 0.5 in TSB supplemented with $0.2 \%$ glucose. Two hundred microliters of the suspension was inoculated to each well except for the medium controls. The microplates were incubated at $37^{\circ} \mathrm{C}$ for $20 \mathrm{~h}$. The percentage of biofilm inhibition was expressed by the following formula: [1 $\left(\mathrm{OD}_{570 \mathrm{~nm}}\right.$ of samples treated with CEN-ZnO NPs/OD $570 \mathrm{~nm}$ of non-treated control samples) $\times 100]$. Positive and negative controls were included.

2.9.2. Tetrazolium chloride (TTC) assay. The TTC solution was obtained by dissolving $0.025 \mathrm{~g}$ of powder TTC in $5 \mathrm{~cm}^{3}$ of deionized water, vortexed and then passed through a 0.22 micron filter. $50 \mu \mathrm{l}$ of TTC solution was added to the microtiter wells, and the plate located in a shaker incubator for 30 minutes. After this time, the absorbance of the resultant solution was evaluated in microtiter plate reader at $570 \mathrm{~nm}^{21}$

2.9.3. Crystal violet assay (CV assay). First, we rinsed the microtiter plate thrice with sterile PBS; then, $125 \mu$ l of $0.1 \%$ crystal violet (Merck, Germany) solution was added to each well. After 10 minutes at room temperature, the wells were discharged, and the microplates were carefully washed under running tap water to remove surplus $\mathrm{CV}$ dye. Next, acetic acid $30 \%$ was added for 10 minutes. After this time, $125 \mu \mathrm{l}$ of each well was transferred into the new microplate and read through the microtiter plate spectrometry at a wavelength of $570 \mathrm{~nm} .{ }^{22}$

2.9.4. Determination of minimum biofilm eradication concentrations (MBEC) of CEN-ZnO NPs. In this research, the effect of the CEN-ZnO NPs on one-, three-, and five-day-old biofilms were examined. As mentioned above, the biofilms were established in microtiter plates (Sigma Aldrich, St. Louis, Missouri, USA). After 24, 48, or 72 hours, the media were removed from the wells, and the plates were washed thoroughly with PBS $(\mathrm{pH}=7.4)$ to remove the unattached cells. After that, two-fold serial dilutions of CEN-ZnO NPs were made in wells in 
a way that five different concentrations were tested. In our study, the designated concentrations were from 64 to $2500 \mu \mathrm{g}$ $\mathrm{ml}^{-1}$. The culture medium of bacteria without CEN-ZnO NPs was added to the well as the control. The plates were incubated for 24 hours at $37^{\circ} \mathrm{C}$ and stained with crystal violet (CV) and TTC.

2.9.5. The analysis of biofilms by confocal laser scanning microscopy (CLSM). Confocal laser scanning microscopy analysis was performed to investigate the effect of the biosynthesized CEN-ZnO NPs on biofilm formed by $S$. aureus and $P$. aeruginosa PAO1. For confocal imaging of the biofilms, they were grown on glass coverslips and microtitre plates. ${ }^{23}$ In summary, six-well microtiter plate seeded with glass coverslips were incubated for $24 \mathrm{~h}$ at $37^{\circ} \mathrm{C}$ in $5 \mathrm{ml}$ of TSB with $2 \%$ glucose. The wells were inoculated with $1000 \mu \mathrm{l}$ of mid-exponential grown cultures. After $24 \mathrm{~h}$, the CEN-ZnO NPs at their MBEC concentrations were added to the overnight grown bacterial cultures and were incubated at $37{ }^{\circ} \mathrm{C}$ for $24 \mathrm{~h}$. The coverslips were removed and gently rinsed with sterile PBS and then stained with $15 \mu \mathrm{l}$ propidium iodide (PI; Sigma) for $15 \mathrm{~min}$ at room temperature to detect red (dead) bacterial cells. After being washed in PBS, the cultures were incubated with $50 \mu \mathrm{l}$ $\mathrm{ml}^{-1}$ of fluorescein isothiocyanate (FITC-Sigma) for $15 \mathrm{~min}$ at room temperature to stain the glycocalyx matrix green (live). PI is excited at $520 \mathrm{~nm}$, the emission monitored at $620 \mathrm{~nm}$, and FITC is excited and observed at 495 and $525 \mathrm{~nm}$, respectively. ${ }^{24}$ The untouched biofilms were examined using a confocal electron microscope Leica TCS SP5 II.

\subsection{Assessment of bacterial viability by flow cytometry}

The bacterial cells including P. aeruginosa PAO1, E. coli ATCC 25922, and $S$. aureus ATCC 25923 were selected to determine the cell viability and internalization after exposure to the biosynthesized CEN-ZnO NPs by flow cytometry. Briefly, for cell viability assessment, afresh grown suspensions of the bacterial strains $\left(1 \times 10^{8}\right.$ $\mathrm{CFU} \mathrm{ml} \mathrm{m}^{-1}$ ) were treated with increasing concentrations of CEN-ZnO NPs $\left(500,1500\right.$, and $2500 \mu \mathrm{g} \mathrm{ml}^{-1}$ for E. coli and P. aeruginosa and 16, 32, and $64 \mu \mathrm{g} \mathrm{ml} \mathrm{m}^{-1}$ for $S$. aureus) at $37{ }^{\circ} \mathrm{C}$ under shaking condition (110 rpm) in a shaker incubator for $20 \mathrm{~h}$. The bacterial viability was assessed using a flow cytometer BD FACS Calibur (BD Biosciences, San Jose, CA, USA) equipped with an argon laser device (excitation at $488 \mathrm{~nm}$, emission $530 \mathrm{~nm}$ ), and the flow cytometric graphs drawn with the FLOWJO 10.4.2 software that was made available on https:/www.flowjo.com/solutions/. For laser calibration purpose and gating selection, unstained and single-stained FDA or PI bacteria were also assessed. The setup procedure for flow cytometry analysis was designed as described elsewhere follows: a fluorescein diacetate (FDA) (Sigma Chemicals F7378) stock solution was prepared by dissolving $10 \mathrm{mg}$ FDA in $10 \mathrm{ml}$ acetone and stored in the dark at $-20{ }^{\circ} \mathrm{C}$ until further use. A working solution was prepared by mixing $10 \mu \mathrm{l}$ of stock solution with $2.5 \mathrm{ml}$ of distilled water (this solution is stable for only $20 \mathrm{~min}$ and should, therefore, be prepared freshly). The working solution was added to each reaction and kept at room temperature for $15 \mathrm{~min}$ in dark condition. Unstained samples were used for light scatter gating, and the control was the sample without CEN-ZnO NP treatment.
2.10.1. Internalization assay. Propidium iodide (PI) staining was used as the dye to check the permeability of the bacteria that were exposed to CEN-ZnO NPs. For this purpose, a fresh culture of the bacterial strains prepared as the bacterial concentration was $1 \times 10^{8} \mathrm{CFU} \mathrm{ml}^{-1}$ and exposed to the NP concentrations of 500,1500 , and $2500 \mu \mathrm{g} \mathrm{ml} \mathrm{m}^{-1}$ for $E$. coli and $P$. aeruginosa and 16, 32, and $64 \mu \mathrm{g} \mathrm{m} \mathrm{m}^{-1}$ for S. aureus for 30 minutes. Subsequently, $2 \mu \mathrm{l}$ of PI $(20 \mu \mathrm{M})$ was added to the samples for $15 \mathrm{~min}$ in darkness at room temperature. Briefly, 50 $\mu \mathrm{l}$ of the treated cells were added to $950 \mu \mathrm{l}$ of $1 \times$ PBS, mixed thoroughly and analyzed using flow cytometer BD FACS Calibur (BD biosciences, San Jose, CA, USA).

\subsection{Cell culture and cytotoxicity assay (in vitro)}

The human lung fibroblast cell line MRC-5 and the cancerous human lung alveolar epithelial cell line A549 were kindly provided by the cell bank of Pasture Institute of Iran and used as in vitro models of normal and cancerous lung cell lines, respectively. They were grown in RPMI/DMEM culture medium, respectively, containing $10 \%$ fetal bovine serum in a $5 \% \mathrm{CO}_{2}$ atmosphere and a relative humidity of $90 \%$ at $37{ }^{\circ} \mathrm{C}$. The cultured cells were treated with different concentrations of $\mathrm{ZnO}$ NPs $\left(10,50,100\right.$, and $\left.200 \mu \mathrm{g} \mathrm{ml}^{-1}\right)$. The viability of the cells treated with CEN-ZnO NPs was examined by the MTT test. The percentage of cell viability was assessed using the MTT assay using the following protocol. In brief, the cells $\left(1 \times 10^{4}\right)$ were seeded in 96-well culture plates and allowed to adhere for $24 \mathrm{~h}$ under a high-humidity environment with $5 \% \mathrm{CO}_{2}$ and $95 \% \mathrm{O}_{2}$ atmosphere at $37{ }^{\circ} \mathrm{C}$. The cells were then exposed to various concentrations $\left(10-200 \mu \mathrm{g} \mathrm{ml}^{-1}\right)$ of CEN-ZnO NPs for $24 \mathrm{~h}$. After exposure, $10 \mu \mathrm{l}$ of MTT stock solution (5 $\mathrm{mg}$ MTT in $1 \mathrm{ml} 1 \times$ PBS) was added and the plate incubated for $4 \mathrm{~h}$ at $37{ }^{\circ} \mathrm{C}$. Afterward, the solution was removed, and isopropanol added to the cells to create purple crystal formazan. To better dissolve the MTT sediment, the plate was placed on a shaker for 15 minutes. Then, the concentration of the dissolved material in isopropanol was calculated using an ELISA reader (STAT FAX 2100, USA) at a wavelength of $545 \mathrm{~nm}$. The wells with more cells have higher optical density (OD) than the well with lesser cells. Therefore, the following equation was used to determine the wells with more cells and compared with the control sample.

$$
\text { Toxicity } \%=1-\frac{\text { mean OD of sample }}{\text { mean OD of control }} \times 100
$$

$$
\text { Viability } \%=100-\text { toxicity } \%
$$

\subsection{ROS level analysis}

The ROS level was assayed by a fluorimetric assay using $2^{\prime}, 7^{\prime}$ dichlorofluorescin diacetate (DCFHDA; Sigma). The bacterial cells were treated with different concentrations of CEN-ZnO NPs $\left(500,1000,1500\right.$, and $2500 \mu \mathrm{g} \mathrm{ml}^{-1}$ for $E$. coli and $P$. aeruginosa and $8,16,32$, and $64 \mu \mathrm{g} \mathrm{m}{ }^{-1}$ for $S$. aureus) and incubated with 
DCFH-DA (10 mM) for $30-60 \mathrm{~min}$ at $37^{\circ} \mathrm{C}$ and then centrifuged at $4000 \mathrm{rpm}$. Subsequently, the cells were washed with PBS. The conversion of DCFH to dichlorofluorescein (DCF) was monitored using a fluorescence spectrophotometer with excitation and emission wavelengths at 480 and $520 \mathrm{~nm}$, respectively.

\section{Results}

\subsection{Identification of the selected cyanobacterial isolate}

Light microscopy and SEM revealed the isolation, purity, and morphology of the cyanobacterial strain. The selected cyanobacterial isolate forms filamentous structures and is straight or curved to some extent. Molecular analysis of 16S rRNA gene sequences of the strains disclosed that the selected cyanobacterial isolate belongs to the genus of Nostoc. The cyanobacterial strain was identified and tentatively designated as Nostoc sp. EA03 and the sequence (1260 bp) deposited in GeneBank through the accession number of KY947487.1 (Fig. 1a-c).

\subsection{GC-MS analysis of cyanobacterial cell extract}

GC-MS chromatogram of methanolic extract of Nostoc sp. EA03 along with their retention time (RT) is shown in Table 1. The major components present in the methanol extract of Nostoc sp. EA03 along with the molecular formula, molecular weight, and peak area are presented in Table 1 and Fig. 2. The GC-MS chromatogram of methanolic extract of Nostoc sp. EA03 cell extract showed the presence of several active principle compounds. Fifteen compounds were identified in the methanolic extract of Nostoc sp. EA03 cells. The main compounds were $n$-hexadecanoic acid (39.76\%), 9-octadecenoic acid (19.72\%), octadecadienoic acid (8.67\%), hexadecenoic acid (8.11\%), octadecanoic acid $(4.11 \%)$, benzenedicarboxylic acid $(2.25 \%)$, heptadecane $(2.07 \%)$, phytol $(1.73 \%)$, hexadecane $(0.77 \%)$, and triphenylphosphine oxide $(1.21 \%)$. Therefore, fatty acids, palmitic acid, and phytol could be the likely candidates elaborated in the capping $\mathrm{ZnO}$ at the nanoscale, besides proteins and other ancillary phytochemicals, which needs to be determined in further studies. The existence of algal metabolite hexadecanoic acid (palmitic acid), as a stable and abundant molecule in the cyanobacterial cell extract, can form a dense coating on the surface of the nanoparticles, enhancing its hydrophobic properties.

\subsection{Biosynthesis of CEN-ZnO NPs and optimization}

The cell extract of Nostoc sp. EA03 was added to an aqueous zinc acetate solution, resulting in a change in color from dark green to white (Fig. 3a-d). The UV-Vis absorption spectra of the biosynthesized CEN-ZnO NPs have shown in Fig. 4a. As illustrated, the surface plasmon resonance (SPR) band centered at $370 \mathrm{~nm}$ confirms the formation of ZnO NPs in the solution, whereas no absorption band was determined for zinc acetate and the cell extract at the same region. Similar to the result obtained in our study, Jayaseelan et al. ${ }^{25}$ observed a sharp peak in the $374 \mathrm{~nm}$ region as a result of ZnONPs synthesis using A. hydrophila biomass. Also, our results were completely consistent with a previous report by Singh et al. ${ }^{26}$ that a similar pattern of peaks obtained from the synthesized zinc oxide nanoparticles using cyanobacterium Anabaena strain L3. The effect of $\mathrm{pH}$ and cell extract concentration on the UV absorption pattern of CEN-ZnO NPs was also checked. The results showed different concentration of the characteristic band of ZnO NRs at $370 \mathrm{~nm}$ as a function of cell extract concentration without any change in the peak wavelength. The maximum production of CEN-ZnO NPs occurred when the final concentration of the cell extract in the reaction mixture was $1 \mu \mathrm{l}$ (Fig. 4b). The same investigation on the effect of $\mathrm{pH}$ on the yield of CNE-ZnO NPs also showed that the maximum production of $\mathrm{ZnO}$ NPs occurred at $\mathrm{pH}$ 9, while other $\mathrm{pH}$ values showed lower production of CENZnO NPs, as represented in Fig. 4c. Since the synthesis was carried out at room temperature (lack of high-temperature and alkaline requirements), this study appeared to be a significant method for eco-friendly synthesis of ZnO NPs. Based on the results, the amount of fatty acids, especially palmitic acid, is being present in more than the other metabolites in the cell extract. It is therefore suggested that the palmitic acid play an important role as a reducing agent during the green synthesis of the zinc oxide nanoparticles.

\subsection{Characterization of CEN-ZnO NPs}

3.4.1. XRD analysis. The structure of the synthesized CENZnO NPs was analyzed by XRD analysis (Fig. 4d). Peaks were observed at $2 \theta$ values of $31.59^{\circ}, 34.22^{\circ}, 36.08^{\circ}, 47.40^{\circ}, 56.40^{\circ}$, $62.62^{\circ}$, and $67.75^{\circ}$ which can be indexed to (100), (002), (101), (102), (110), (103), and (112). The XRD pattern was comparable with the reference pattern (JCPDS card no. 89-7102) corresponding to the star-like structure of ZnO NPs. ${ }^{26}$ The observed intense peaks also showed the high purity and crystalline structure of the synthesized ZnO NPs.

3.4.2. FTIR spectroscopy. The chemical structure $\mathrm{ZnO}$ and the biosynthesized CEN-ZnO NPs was also studied by FTIR spectroscopy (Fig. 5a). An absorption band, found at $3382 \mathrm{~cm}^{-1}$, indicates the presence of $\mathrm{O}-\mathrm{H}$ hydrogen bands. The two prominent peaks of proteins were observed at $1650 \mathrm{~cm}^{-1}$ (amide I, C $=\mathrm{O}$ stretching) and $1550 \mathrm{~cm}^{-1}$ (amide II, C-N stretching and $\mathrm{N}-\mathrm{H}$ deformation). The peak at $1386.49 \mathrm{~cm}^{-1}$ represents the $\mathrm{N}-\mathrm{O}$ functional group. The high intensity band at $\sim 547.38 \mathrm{~cm}^{-1}$ is the result of the presence of the oxygen and zinc bands. A peak at $1651 \mathrm{~cm}^{-1}$ in the biosynthesized CEN-ZnO NPs, by Nostoc sp. EA03, is as a result of amide group that is characteristic of the protein. The peak in the region of $1206 \mathrm{~cm}^{-1}$ is due to the presence of the $\mathrm{C}-\mathrm{O}$ functional group. The analysis of cyanobacterial cell extract showed an absorption peak at $1626.96 \mathrm{~cm}^{-1}$ that may correspond to free $\mathrm{C}=\mathrm{O}$ groups, while in CEN-ZnONPs, the absorption peak in the region of $1513 \mathrm{~cm}^{-1}$ resulted from the presence of carboxylate group $\left(\mathrm{COO}^{-}\right)$. An absorption peak at the region of $2962.78 \mathrm{~cm}^{-1}$ indicates the presence of the $-\mathrm{C}-\mathrm{H}$ stretches of the alkyl (methyl) group. For all doped and undoped $\mathrm{ZnO}$ samples the absorption peaks in the range of $400-700 \mathrm{~cm}^{-1}$ could be assigned to the $\mathrm{ZnO}$ stretching modes. The presence of absorption peaks in the region of 416.14 and $489.98 \mathrm{~cm}^{-1}$ in the CEN-ZnONPs sample represents the ZnO core, while this peak 

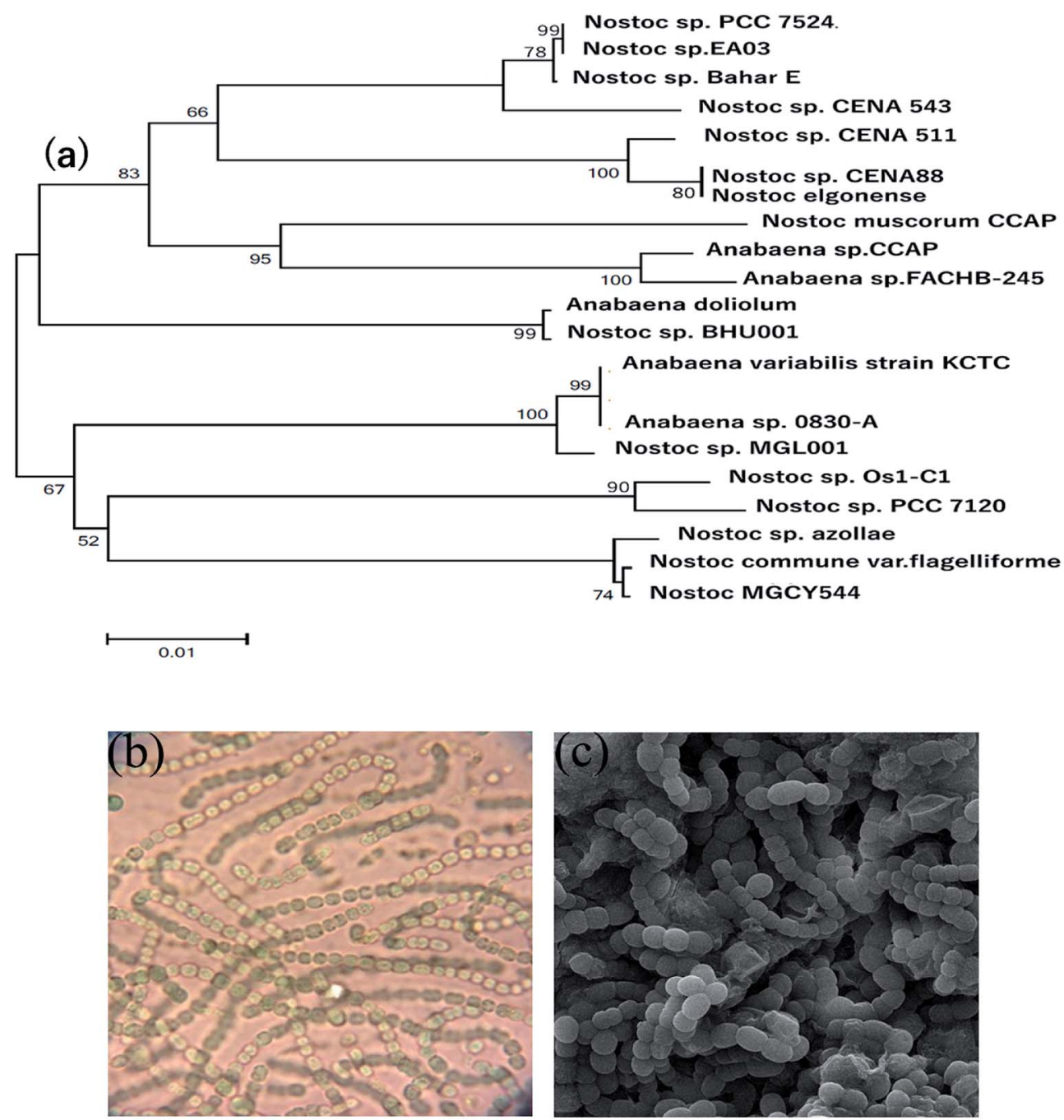

Fig. 1 (a) Phylogenetic tree of the strains Nostoc sp. EA03, (b) illustration of the light microscope, (c) scanning electron microscopy (SEM) image of Nostoc sp. EA03.

was not observed in cellular extracts and unalloyed ZnO. The absorption peak at $1626 \mathrm{~cm}^{-1}$ confirms the presence of $\mathrm{C}=\mathrm{O}$ groups in the cell extract. The absorption peaks in the region
$1352 \mathrm{~cm}^{-1}$ and $1044 \mathrm{~cm}^{-1}$ in the cell extract, respectively, indicates the presence of $\mathrm{C}=\mathrm{C}$ and $\mathrm{C}-\mathrm{O}$. An absorption peak at $1030 \mathrm{~cm}^{-1}$ in CEN-ZnONPs may correspond to the presence of

Table 1 Different compounds of cell extract of the Nostoc sp. EA03 and their activities identified by gas chromatography mass spectrometry (GC-MS)

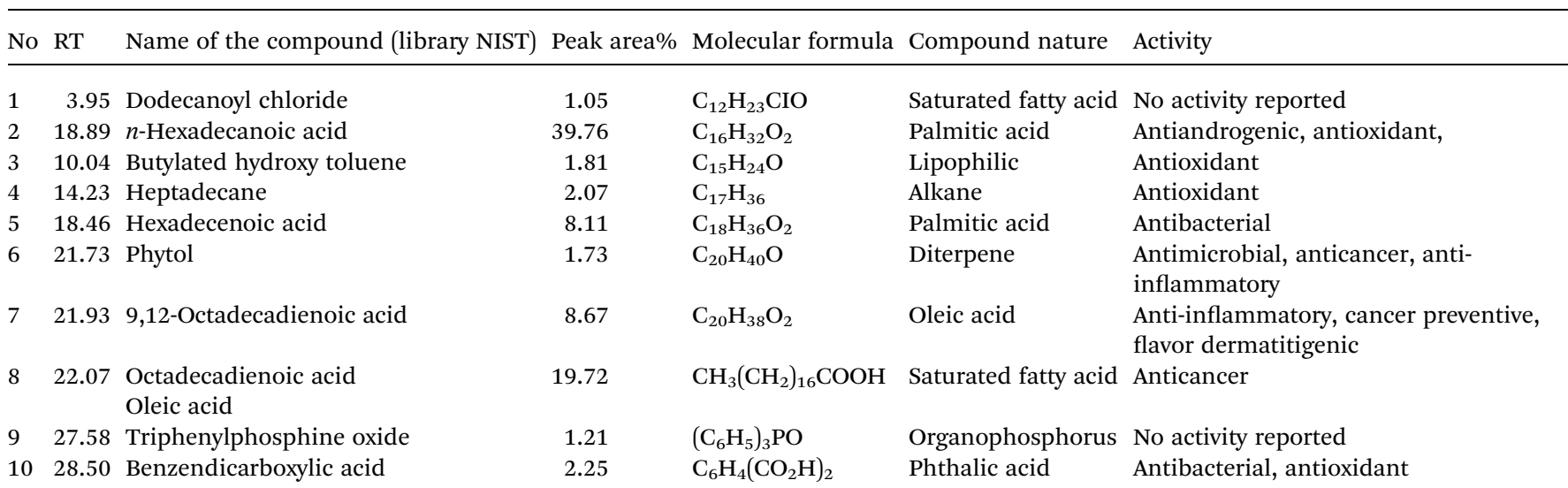




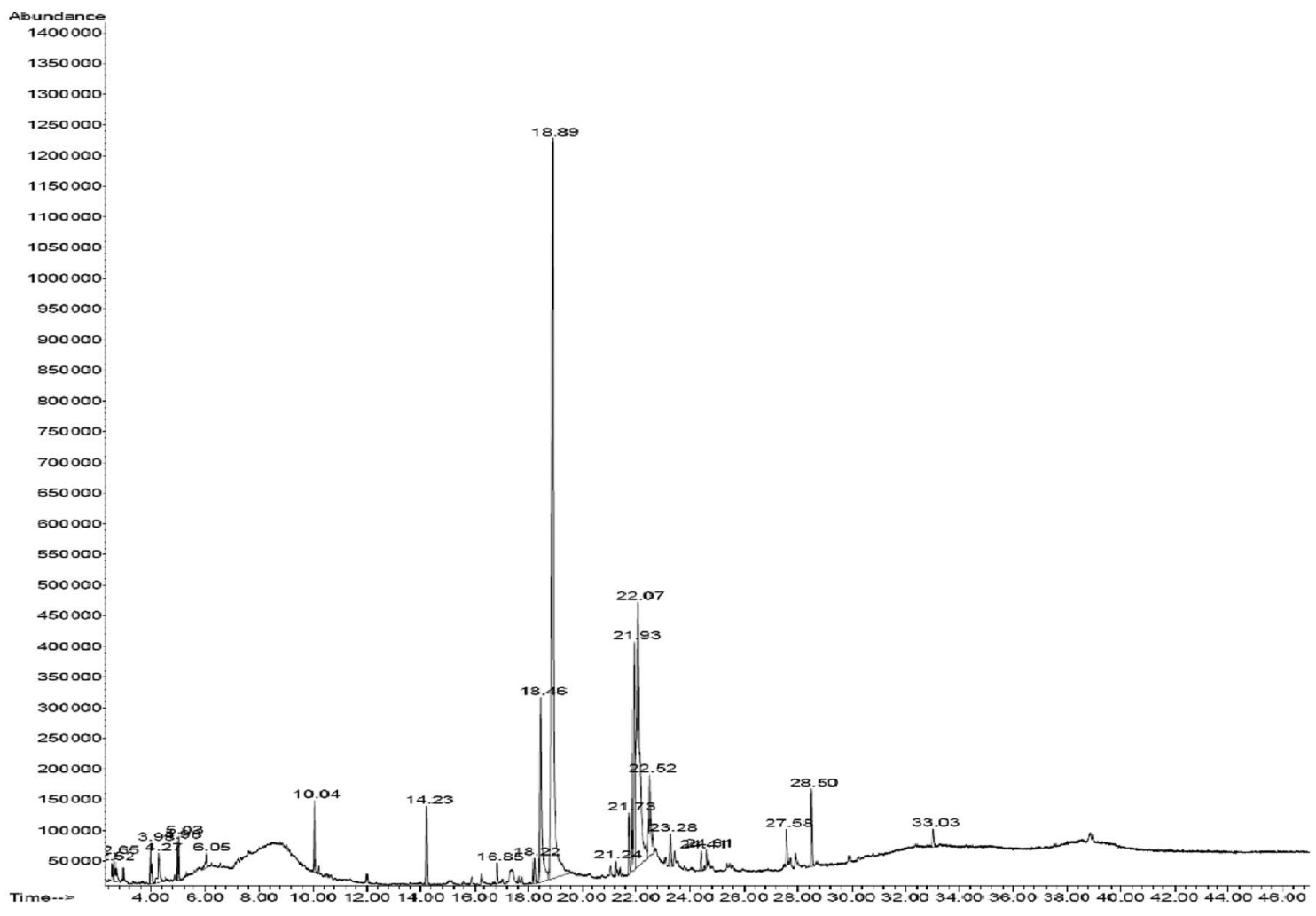

Fig. 2 GC-MS chromatograms of the methanol extract of Nostoc sp. EA03 cells.

$\mathrm{C}-\mathrm{O}$. The peak at $3257 \mathrm{~cm}^{-1}$ confirms the presence of the hydroxyl $(\mathrm{O}-\mathrm{H})$ groups. It can therefore be supposed that the nanoparticle is synthesized and stabilized by replacing the acids with methyl and hydroxyl groups.

Having a negative zeta potential value of -29.7 suggests that the bioactive molecules play a role in the stability of nanoparticles for a long time (Fig. $5 b$ ). Fig. $5 c$ shows the TGA/ DSC curve of the biosynthesized zinc oxide nanoparticles using cyanobacterial cell extracts (CEN-ZnO NPs). As can be seen, the slope is initially constant and progresses horizontally, indicating that the material is pure and does not contain any impurities or moisture. The sample does not show any change in weight up to $120{ }^{\circ} \mathrm{C}$, representing that it has an appropriate range. A gradual weight loss of $7.84 \%$ is likely due to a loss of moisture. The weight loss of the nanoparticles was about $0.31 \mathrm{mg}$. As the temperature increases, the mass of the sample decreases. The peak at $139.58{ }^{\circ} \mathrm{C}$ may be due to the evaporation of water absorbed by the surface of the product or the loss of volatile surface molecules absorbed on the surface of the zinc complex during the synthesis conditions, while the peak in the region of $220^{\circ} \mathrm{C}$ shows the conversion of zinc to zinc oxide. The area from $419{ }^{\circ} \mathrm{C}$ onwards is allocated to the formation of nanoparticles and the deformation of organic matters (Fig. 5c).

3.4.3. SEM, TEM, and EDX analysis. The SEM micrograph of the synthesized CEN-ZnO NPs has shown in Fig. 6a. As illustrated, in the $69000 \times$ magnification and at an accelerating voltage of $20 \mathrm{kV}$, the particles were star-shaped with an average diameter of $60 \mathrm{~nm}$. The TEM image further confirmed that the biosynthesized CEN-ZnO NPs have a star-like shape, small width-to-length ratio, with a mean diameter of around 50$80 \mathrm{~nm}$ (Fig. 6b). This is also close to the crystalline size of CENZnO NPs as estimated by Scherer's formula as confirmed by the XRD results.

The chemical composition of the CEN-ZnO NPs was investigated by EDX analysis (Fig. 6c). The results of the EDX analysis of ZnO NPs show three emission peaks of metal zinc comprising $31.80 \%$ and one emission peak of oxygen comprising $63.20 \%$. This observation clearly confirms the successful synthesis of pure CEN-ZnO NPs. Moreover, EDX results further confirm the presence of zinc in its oxide form, showing that the biosynthesis of ZnO NPs present as an efficient means of processing.

\subsection{Determination of MIC and MBC, biofilm assay}

The MIC values of the biosynthesized CEN-ZnO NPs for $E$. coli ATCC 59222, S. aureus ATCC 59223, and P. aeruginosa PAO1 were 2000,64 , and $2000 \mu \mathrm{g} \mathrm{ml}^{-1}$, respectively, while the MBC values were 2500,128 , and $2500 \mu \mathrm{g} \mathrm{ml}^{-1}$, respectively (Table 2). The maximum MIC and MBC values were 2000 and 2500 $\mu \mathrm{g} \mathrm{ml} \mathrm{m}^{-1}$ for E. coli and P. aeruginosa, respectively. The biofilm inhibition appeared with increasing concentrations of the biosynthesized CEN-ZnO NPs up to $2500 \mu \mathrm{g} \mathrm{ml}^{-1}$. The rate of biofilm inhibition for the biosynthesized CEN-ZnO NPs concentrations of $128,256,500,1500$, and $2500 \mu \mathrm{g} \mathrm{ml}{ }^{-1}$ was $9.49 \%, 22.15 \%, 36.30 \%, 42.67 \%$, and $87.30 \%$ in $E$. coli 


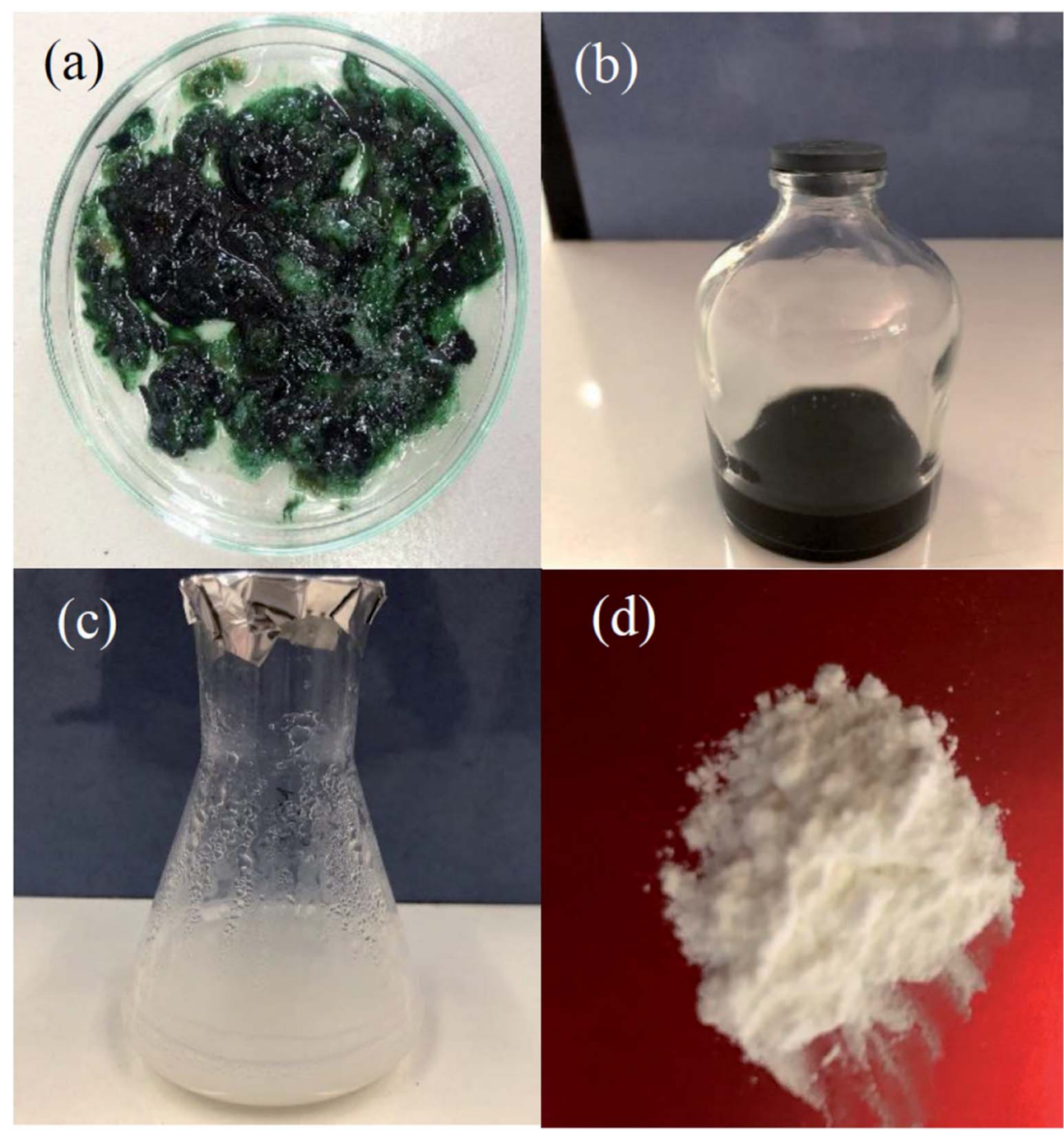

Fig. 3 (a) The biomass of Nostoc sp. EA03; (b) purified cell extract; (c) CEN-ZnO NRs; (d) CEN-ZnO powder.

(Fig. 7a), and $51.32 \%, 53.53 \%, 54.42 \%, 55.75 \%$, and $80 \%$ in $P$. aeruginosa (Fig. 7b). The rate of biofilm inhibition for $S$. aureus at concentrations of $8,16,32$, and $64 \mu \mathrm{g} \mathrm{m} \mathrm{m}^{-1}$ was $26.35 \%, 57.36 \%, 69.11 \%$, and $82.86 \%$ (Fig. $7 \mathrm{c}$ ).

\subsection{Eradication of biofilm formation by CEN-ZnO NPS}

The biofilm eradication showed that the CEN-ZnO NPs had no significant effect on 3 and 5 days old biofilms, whereas the biosynthesized CEN-ZnO NPs had a significant effect on one day old biofilms. The eradication activity of the NP treatment for $P$. aeruginosa was more pronounced compared to $E$. coli and $S$. aureus. The absorbance value of the biofilm dissolved in $33 \%(\mathrm{v} / \mathrm{v})$ acetic acid in the microplate at $562 \mathrm{~nm}$ was used to evaluate quantitatively the amount of biofilm eradicated from the test material. The results showed that the activity of CEN-ZnO NPs was highest at the concentration of $2 \mathrm{mg} \mathrm{ml} \mathrm{m}^{-1}$, with an inhibition rate of $88.50 \%$ for $P$. aeruginosa (Fig. $7 \mathrm{~d}$ ), and $84.16 \%$ for $E$. coli (Fig. 7e). The inhibition rate for $S$. aureus, at a concentration of $64 \mu \mathrm{g} \mathrm{ml} \mathrm{m}^{-1}$, was $71.53 \%$ (Fig. 7f).

\subsection{Cell viability}

The potential cytotoxic behavior of green synthesized ZnO NPs using Nostoc sp. EA03 cell extract against the A549 and MRC-5 cell lines were examined. As shown in Fig. 8a and b, CEN-ZnO NPs do not have any significant effect on the proliferation of A549 and MRC-5 cells at low concentrations; however, when the concentration of CEN-ZnO NPs reached $100 \mu \mathrm{g} \mathrm{ml}^{-1}$, it resulted in a significant decrease in cell viability compared with the control subject. Based on the results, the initial concentration of $50 \mu \mathrm{g} \mathrm{ml}^{-1}$ can be considered as the threshold concentration, at which the toxicity is notably raised $(P \geq 0.05)$. However, there were less toxicity, and at a dosage of 50,100, and $200 \mu \mathrm{g} \mathrm{ml}^{-1}$, the percentage of viable cells was $23 \% \pm 06 \%, 13 \% \pm 02 \%$, and $9 \% \pm 44 \%$, respectively. The cell extract had no significant effects on the cell viability at 50, 100, and $200 \mu \mathrm{g} \mathrm{ml}$ concentrations (Fig. 8a and b). At $50 \mu \mathrm{g} \mathrm{m} \mathrm{m}^{-1}$ concentration, CEN-ZnO NPs eliminates $50 \%$ of the cancer cells (A549); this concentration kills less than $50 \%$ of the healthy cells (MRC-5). The obtained results showed that the CEN-ZnO NPs reduced 

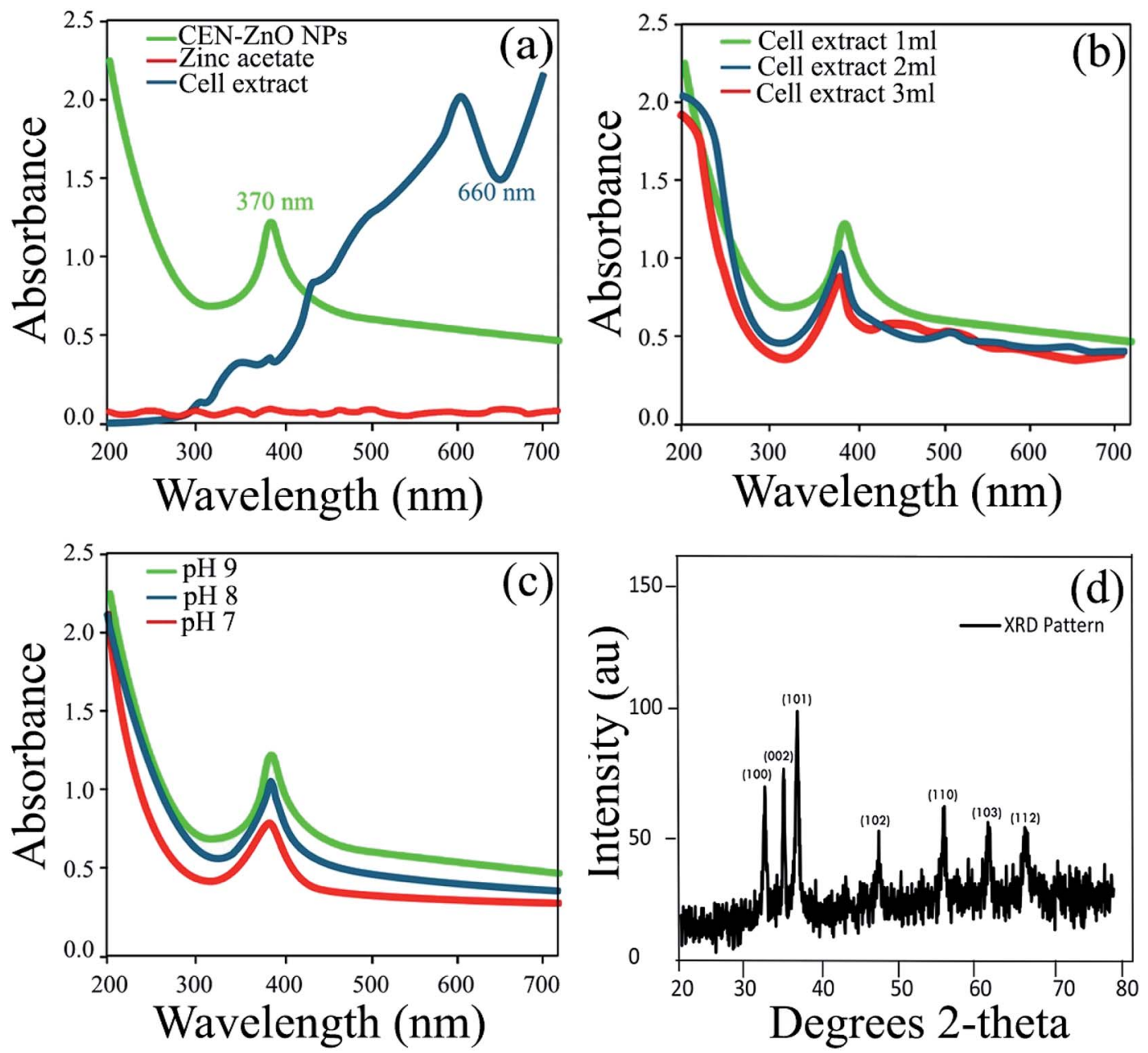

Fig. 4 (a) UV-Vis absorption spectra from 200-700 nm. Green line: CEN-ZnO NPs, blue line: cyanobacterial cell extract, red line: zinc acetate. (b) UV-Vis absorption profiles (200-700 nm) of CEN-ZnO NPs synthesized using different concentrations of cell extract, (c) UV-Vis absorption profiles (200-700 nm) of CEN-ZnO NPs synthesized at different selected pH values, (d) powder X-ray diffraction (XRD) pattern of CEN-ZnO NPs.

the cell viability, and the extent of reduction was concentration/ dose-dependent. As determined through the MTT assay, the A549 cell viability observed at $24 \mathrm{~h}$ was $85.7 \%, 57.36 \%, 23.06 \%$, $13.02 \%$, and $9.44 \%$ (Fig. 8a) in contrast, the MRC-5 cell viability observed at $24 \mathrm{~h}$ was $94.76 \%, 77.94 \%, 58.48 \%, 9.57 \%$, and $5.44 \%$ (Fig. 8b) in response to treatment with 10, 25, 50, 100, and $200 \mu \mathrm{g} \mathrm{ml}^{-1}$ NPs, respectively ( $p<0.05$ for each).

\subsection{ROS assay}

ROS production upon addition of the biosynthesized CEN-ZnO NPS was determined using the fluorescence dye, DCFH-DA, as an indicator for ROS measurement. In presence of $500-2500 \mu \mathrm{g} \mathrm{ml}{ }^{-1}$ of CEN-ZnO NPs, ROS production was much greater and determined to be $316 \pm 4,368 \pm 8,407 \pm 8$, and $769 \pm 6$ in E. coli, $410 \pm 3,550$ $\pm 4,616 \pm 2$, and $786 \pm 9$ in $P$. aeruginosa. In presence of 500-2500 $\mu \mathrm{g} \mathrm{m} \mathrm{m}^{-1}$ of CEN-ZnO NPs, ROS production was much greater and determined to be $316 \pm 4,368 \pm 8,407 \pm 8$, and $769 \pm 6$ in E. coli, $410 \pm 3,550 \pm 4,616 \pm 2$, and $786 \pm 9$ in $P$. aeruginosa. In the case of $S$. aureus, CEN-ZnO NPs at a concentration of 8-64 $\mu \mathrm{g} \mathrm{ml}^{-1}$, induced the ROS generation in cells up to $622 \pm 1,722 \pm 66,746 \pm$
9 , and $768 \pm 51$, respectively. These results indicate a significant reduction in the population of viable bacterial cells. The $P$. aeruginosa and $E$. coli cultures showed a higher level of ROS production with increasing CEN-ZnO NPs concentrations, in comparison with that of $S$. aureus (Fig. 8c and d).

\subsection{Anti-biofilm activity of CEN-ZnO NPs by confocal laser scanning microscopy}

Confocal laser scanning microscopic (CLSM) analysis was performed to evaluate the biofilm formation by bacterial strains $P$. aeruginosa PAO1 (Fig. 9a), and S. aureus ATCC 25923 (Fig. 9b). To observe the bacterial biofilms, two dyes, PI and FITC, were used for staining. The microscopic images suggested the formation of biofilm on coverslip surfaces treated with CEN-ZnO NPs. However, most of the cells were dead (red fluorescence), and a small number of cells distinguished by staining with FITC dye (green fluorescence). The bacterial biofilms not treated with CEN-ZnO NPs, most of the bacterial cells surrounded in a network composed of an extracellular matrix (living cells). In the case of $P$. aeruginosa PAO1, the bacterial cells grown in the presence of $2500 \mu \mathrm{g} \mathrm{ml}^{-1}$ of CEN- 
(a)

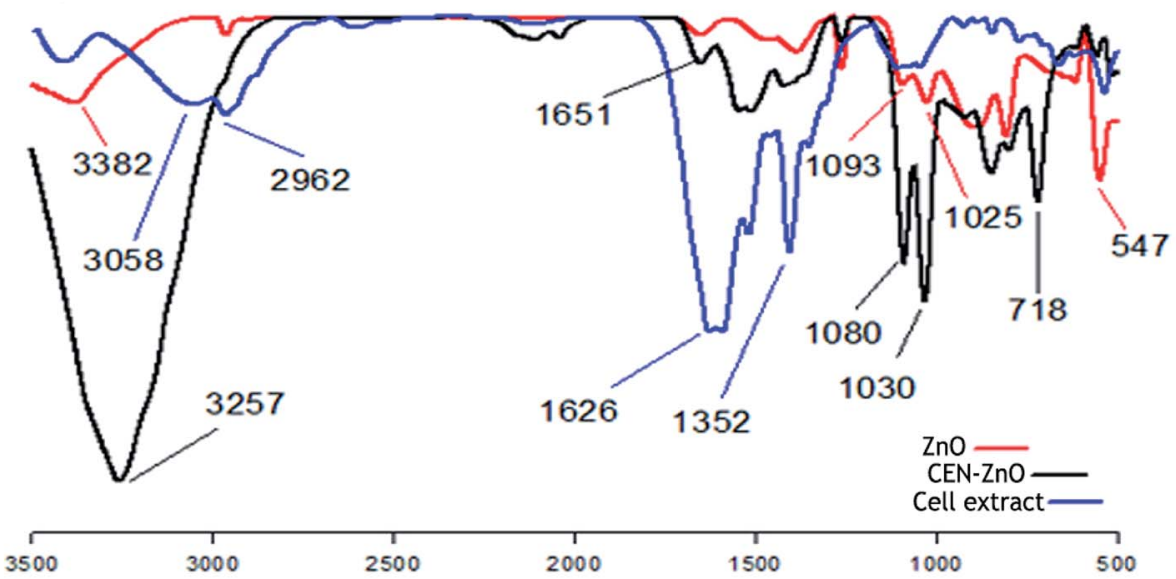

\section{Wavenumber $\left(\mathrm{cm}^{-1}\right)$}

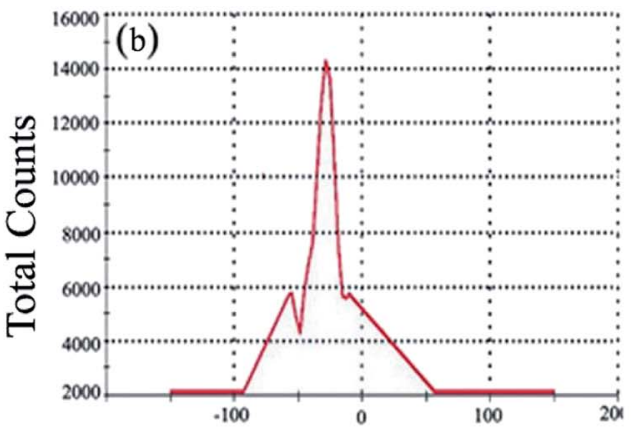

Apperant Zeta Potential (mV)

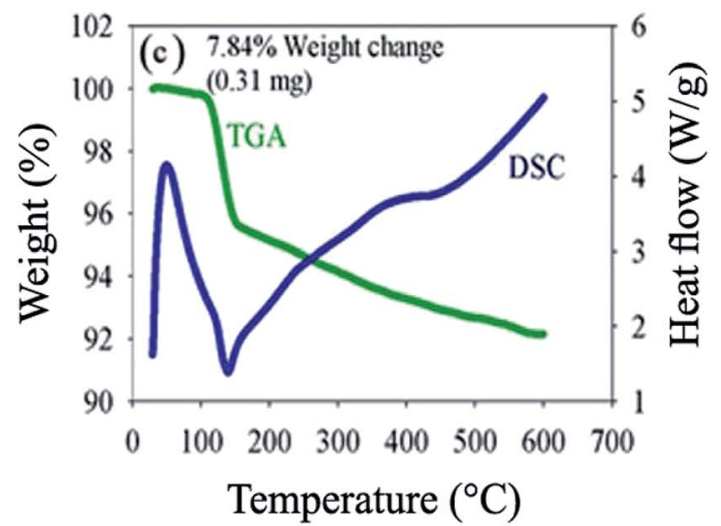

Fig. 5 (a) FTIR profiles of ZnO, CEN-ZnO NPs and cyanobacterial cell extract. (b) Zeta potential distributions for CEN-ZnO NPs. (c) DSC/TGA thermogram profiles of the synthesized CEN-ZnO NPs.

ZnO NPs showed the absence of clumped cells and spread on the surface irregularly. When the CLSM images with red and green fluorescent intensity were placed on top of each other, yellow color appeared. The presence of dark areas among the biofilm might be due to the presence of water channels, heterogeneous matrix production, and all kind of exopolysaccharides inside the biofilms. ${ }^{24}$ The AFM analysis of surface topography of bacterial biofilm samples treated with CEN-ZnO NPs showed a rugged topography in some parts of the biofilm surface, indicating the destruction of biofilms. AFM 3D topographic images also confirmed the results obtained from the changes in surface topography (Fig. 9c-h). In contrast, in the untreated control samples, the structured biofilms was flat and prominent. Overall, CEN-ZnO NPs cause the destruction of the biofilm, as some parts of the biofilm surface seem to be protruding outward or sunken inwards.

\subsection{Flow cytometry analysis}

Data were collected and displayed in bi-dimensional FL1-H versus FL2-H cytograms. Fluorescence (FL1-H/FL2-H) was tested from bacterial cells inside gate LL (Fig. 10). As shown, $P$. aeruginosa PAO1 (Fig. 10a), E. coli ATCC 25922 (Fig. 10b), and $S$. aureus ATCC 25923 (Fig. 10c) exhibited a low sensitivity to CEN$\mathrm{ZnO}$ NPs at concentration of $500 \mu \mathrm{g} \mathrm{ml}^{-1}$ of, and a slow decrease in cell viability $(87.01 \%, 92.04 \%$, and $89.9 \%$, respectively). In fact, less than $10-12 \%$ of the bacteria were dead at this concentration. CEN-ZnO NPs at concentrations of $1500 \mu \mathrm{g} \mathrm{ml} \mathrm{m}^{-1}$ and $2500 \mu \mathrm{g} \mathrm{ml}^{-1}$, the cell viability of $P$. aeruginosa PAO1 was reduced by more than $20 \%$ and $38 \%$, for $E$. coli by $17.9 \%$ and $23.6 \%$, and for $S$. aureus at a concentration of $32 \mu \mathrm{g} \mathrm{ml} \mathrm{m}^{-1}, 64 \mu \mathrm{g}$ $\mathrm{ml}^{-1}$ by $13 \%$ and $16 \%$, respectively. Higher concentrations of CEN-ZnO NPs resulted in an increase in cell debris formation and cell death.

The bacterial cell stained with PI was measured to examine the internalization. The fluorescent emission of this dye was collected in the FL3 channel. The cell internalization of the control group was almost $2.89 \%$ for $P$. aeruginosa PAO1 and $6.64 \%$ for $S$. aureus, and $3.81 \%$ for E. coli (Fig. 10). As shown in (Fig. 10d-f), P. aeruginosa, E. coli, and S. aureus showed low sensitivity to CEN-ZnO NPs at concentration of $500 \mu \mathrm{g} \mathrm{ml} \mathrm{ml}^{-1}$, with a gentle decrease in cell integrity (cell integrity: $3.34 \%, 9.81 \%$, and $8.11 \%$, respectively). At $1500 \mu \mathrm{g}$ 

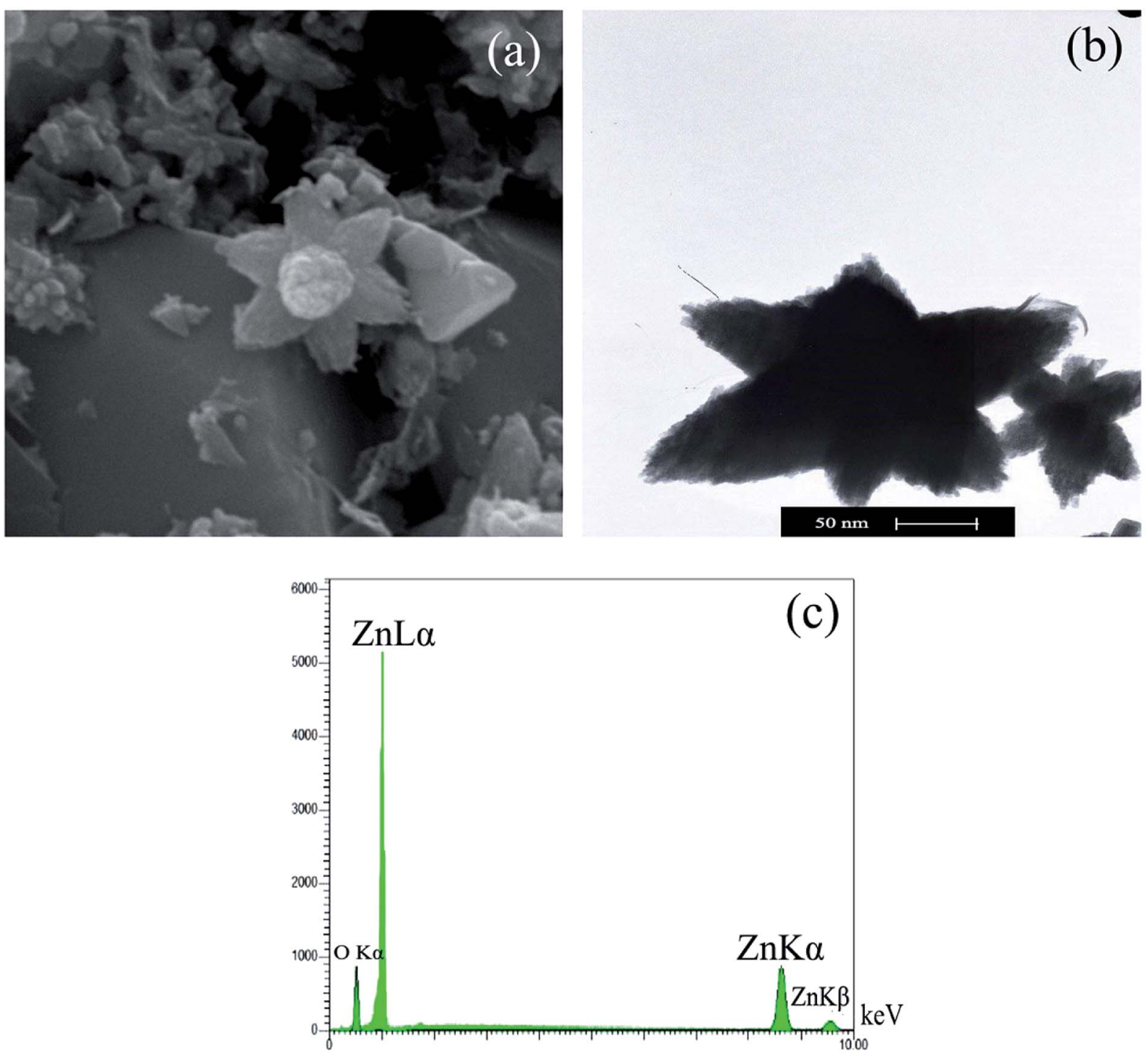

Fig. 6 (a) Scanning electron microscopy (SEM) image of CEN-ZnO NPs; (b) transmission electron microscopy (TEM) image of CEN-ZnO NPs; (c) the analysis of elemental composition of CEN-ZnO NPs recorded by EDX.

$\mathrm{ml}^{-1}$ and $2500 \mu \mathrm{g} \mathrm{ml} \mathrm{m}^{-1}$ concentrations, the cell integrity of $P$. aeruginosa PAO1 was $4.54 \%$ and $7.92 \%$ (Fig. 10d), for E. coli $11.9 \%$ and $14.1 \%$ (Fig. 10e), and for $S$. aureus at a concentration of $32 \mu \mathrm{g} \mathrm{ml} \mathrm{ml}^{-1}, 64 \mu \mathrm{g} \mathrm{ml} \mathrm{m}^{-1}$ was $14.9 \%$ and $17.6 \%$ (Fig. 10f), respectively.

Table 2 MIC and MBC values against tested bacterial strains according to CLSI protocol

\begin{tabular}{|c|c|c|c|c|}
\hline \multirow[b]{2}{*}{ Clinical strains } & \multicolumn{2}{|l|}{ ZnONPs } & \multicolumn{2}{|c|}{ CEN-ZnONPs } \\
\hline & $\begin{array}{l}\text { MIC } \\
\left(\mu \mathrm{g} \mathrm{ml} l^{-1}\right)\end{array}$ & $\begin{array}{l}\mathrm{MBC} \\
\left(\mu \mathrm{g} \mathrm{ml} l^{-1}\right)\end{array}$ & $\begin{array}{l}\text { MIC } \\
\left(\mu \mathrm{g} \mathrm{ml} l^{-1}\right)\end{array}$ & $\begin{array}{l}\mathrm{MBC} \\
\left(\mu \mathrm{g} \mathrm{ml} l^{-1}\right)\end{array}$ \\
\hline E. coli ATCC 25922 & 6500 & 6600 & 2000 & 2500 \\
\hline $\begin{array}{l}\text { S. aureus ATCC } \\
25923\end{array}$ & 3000 & 3500 & 64 & 128 \\
\hline $\begin{array}{l}\text { P. aeruginosa } \\
\text { PAO1 }\end{array}$ & 6500 & 6700 & 2000 & 2500 \\
\hline
\end{tabular}

\section{Discussion}

The biosynthesis of CEN-ZnO NPs was environmentally friendly and did not require high temperatures, high pressures, or harmful chemical compounds. The biosynthesized CEN-ZnO NPs had a higher antimicrobial activity in comparison with unalloyed ZnONPs and cyanobacterial cell extract. In a previous report, it was shown that ZnONPs has more toxic effects against Gram-positive bacteria ( $S$. aureus) than Gram-negative bacteria (P. aeruginosa and E. coli). ${ }^{27}$ They concluded that the difference in the toxicity of nanoparticles might be due to differentiation of the bacterial cell membrane. The results also confirmed that $P$. aeruginosa and $E$. coli are identical in terms of their sensitivity to the equal dose of nanoparticles. The antimicrobial activity of the biosynthesized CEN-ZnO might be due to its star-like shape and its surface-to-volume ratio. In addition, the effectiveness of CEN-ZnO nanoparticles increases with increasing nanoparticle 

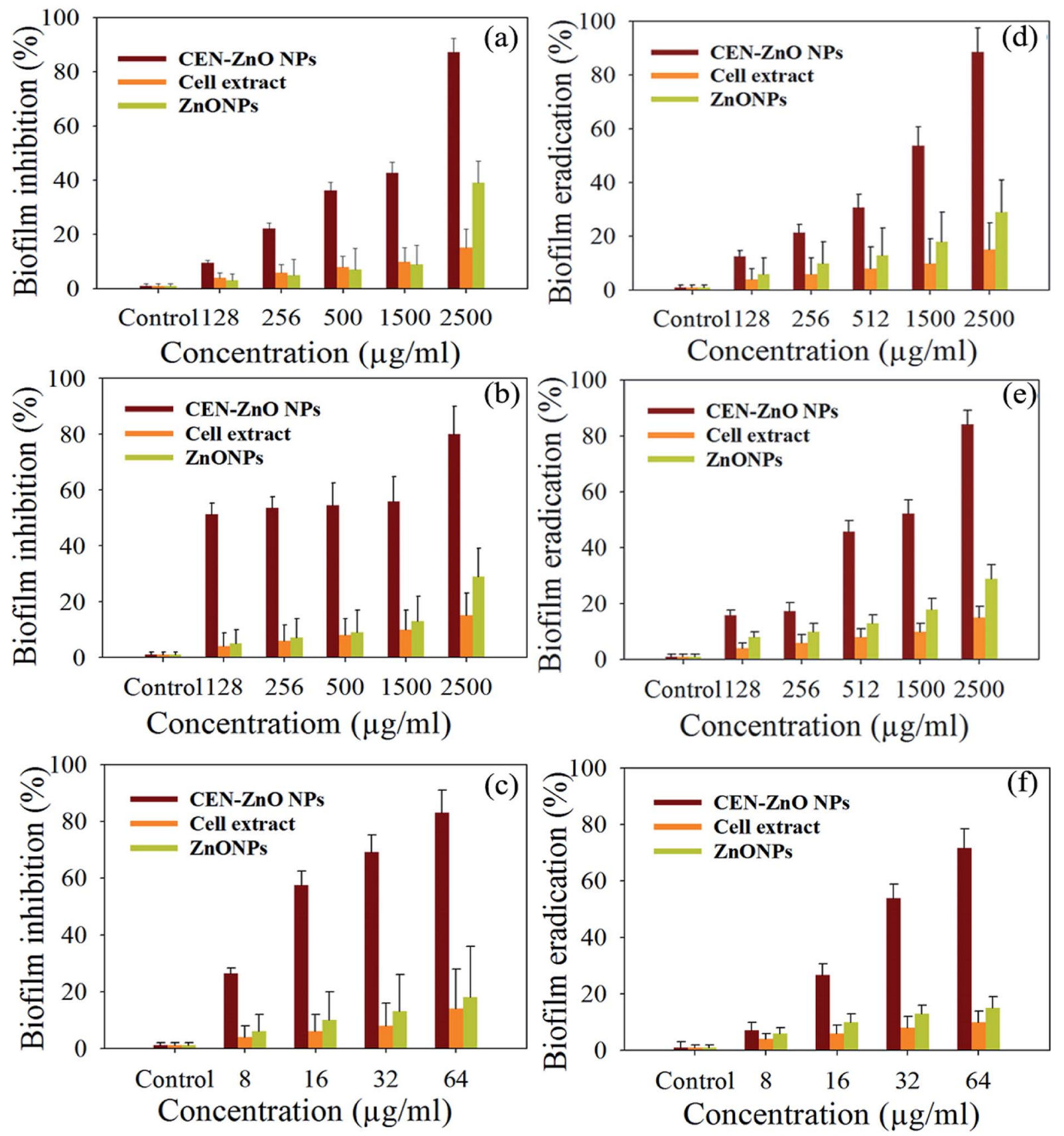

Fig. 7 The inhibitory effects of ZnONPs, cell extract and CEN-ZnO NPs on biofilm formation by (a) E. coli, (b) $P$. aeruginosa, (c) $S$. aureus. *P< 0.05; bars represent the mean of values and error bars represent mean \pm SD. Inhibitory effect of ZnONPs, cell extract and CEN-ZnO NPs on biofilm eradication by (d) P. aeruginosa, (e) E. coli, and (f) $S$. aureus. ${ }^{*} P<0.05$; bars represent the mean of values and error bars represent mean \pm SD.

concentration. Adams et al. ${ }^{28}$ showed that by increasing the concentration of zinc oxide nanoparticles, the antibacterial effects of the nanoparticle against Bacillus subtilis and E. coli increases. In another study, Khursheed et al. ${ }^{29}$ reported that the antibacterial performance (MIC, MBC) of the biosynthesized zinc oxide nanoparticle using Aloe vera extract against Pseudomonas aeruginosa, E. coli (ESBL) and MRSA Staphylococcus aureus were $2200 \mu \mathrm{g} \mathrm{ml}{ }^{-1}, 2400 \mu \mathrm{g} \mathrm{ml}^{-1}$ and $2700 \mu \mathrm{g} \mathrm{m} l^{-1}$, respectively. However, as a result of our research, the biosynthesized CEN-ZnO were reported to have antibacterial activity against $S$. aureus at a lower dose of fewer than $64 \mu \mathrm{g}$ $\mathrm{ml}^{-1}$. Concerning Pseudomonas aeruginosa, the result was in agreement with our study. ${ }^{29}$ The higher antibacterial effects of biosynthesized nanoparticles using Nostoc sp. EA03 is supposedly due to the existence of the bioactive compounds, making an advantage compared to the unalloyed zinc oxide particles. In addition, the antibacterial behavior of ZnONPs can possibly be attributed to the chemical interaction between hydrogen 

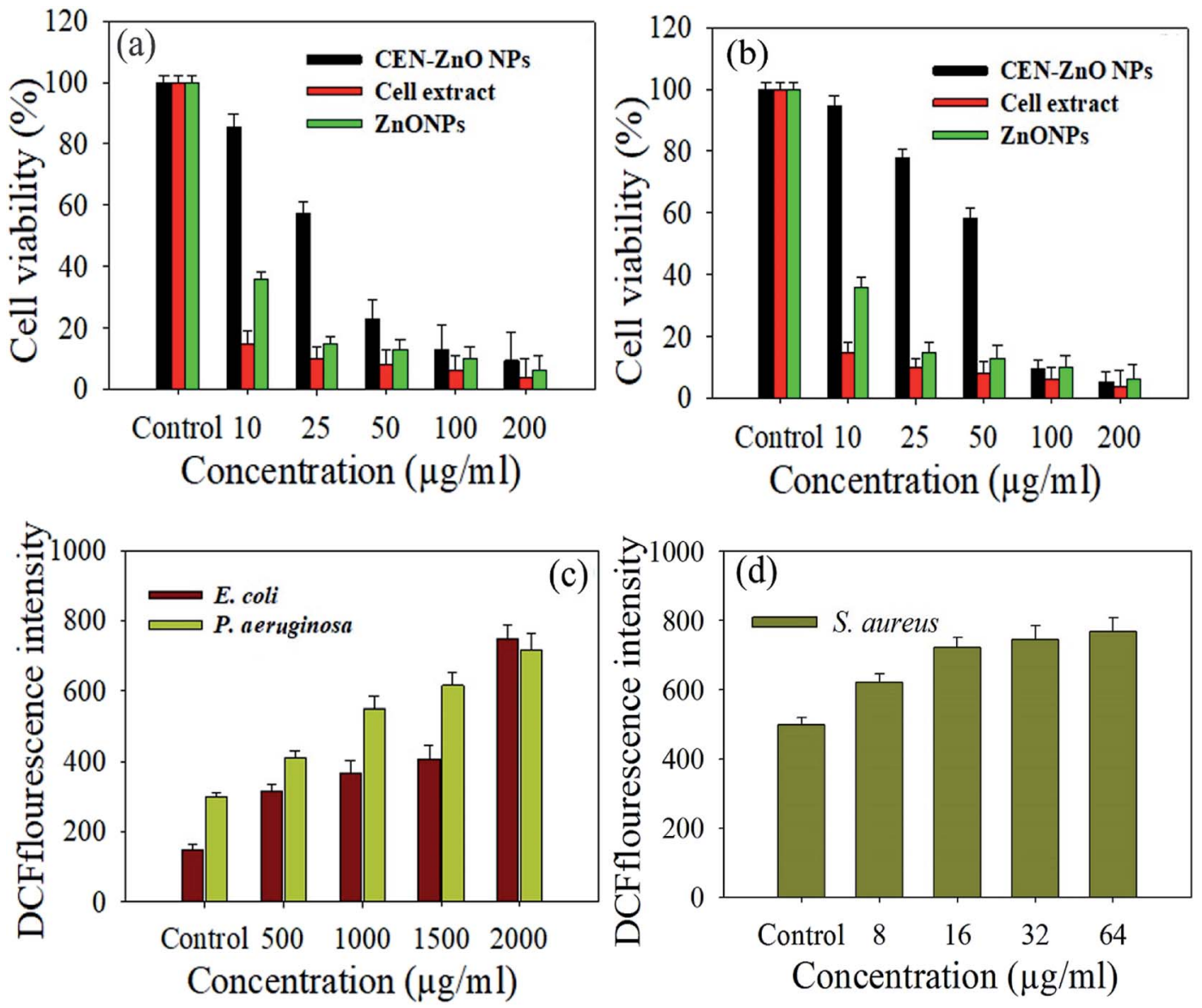

Fig. 8 Histogram representing cell viability based on MTT assay for (a) A549, and (b) MRC-5 cells treated with different concentrations of ZnONPs, CEN-ZnO NPs and cyanobacterial cell extract. Error bars were calculated based on standard deviations of three replications per group $(N=3)$. In vivo measurement of reactive oxygen species (ROS) generation induced by indicated concentrations of CEN-ZnO NPs in bacteria cells, (c) P. aeruginosa, and E. coli, (d) S. aureus. Error bars were calculated based on standard deviations of three replications per group $(N=3)$.

peroxide and membrane proteins or lipid bilayer of bacteria. The produced hydrogen peroxide gets through the bacterial cell membrane and destroys the bacterium. ${ }^{30}$ Rauf et al. Reported the ability of antibacterial activity of biomimetically synthesized $\mathrm{ZnO}$ nanoparticles against $S$. aureus to induce less-sensitive skin infections in experimental animals. They showed that the synthesized ZnONPs could effectively inhibit less susceptible Gram-positive and Gram-negative bacterial isolates. The synthesized ZnONPs also inhibited the biofilm synthesis of tested isolates in vitro and successfully treated the $S$. aureusmediated experimental skin infection in BALB/c mice. ${ }^{31}$ The penetration of CEN-ZnO NPs into the bacterial cells (in line with the results obtained from flow cytometry analysis), increases intracellular accumulation of nanoparticles, thereby destroying bacterial cells. ${ }^{32}$ Malaikozhundan et $a .^{33}$ tested the cytotoxic effects of Pp-ZnO NPs on MCF-7 breast cancer cells and found that single-treatment with $\mathrm{Pp}-\mathrm{ZnO}$ at concentrations greater than $50 \mu \mathrm{g} \mathrm{ml}^{-1}$ reduces cell viability. The toxic effect of biosynthesized CEN-ZnO NPs on A549 lung cancer cells starts at 25

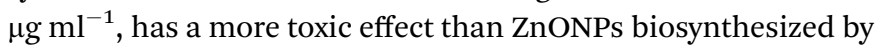
$P$. pinnata seed extract. The biosynthesized CEN-ZnO NPs, at 50 $\mu \mathrm{g}$, destroyed $77 \%$ of cancerous cells (A549) (i.e., $23 \%$ of cells were alive), whereas $\sim 59 \%$ of the cells were remained alive after treatment of the healthy lung cells (MRC-5) with a similar concentration. This means that CEN-ZnO NPs, in a similar concentration, eliminate cancerous cells twice as higher than healthy cells. Our results were almost close to those findings that showed a 50\% reduction in human lung cancer cells A549 and breast cancer cells MCF-7 after treatment with ZnONPs at a concentration of $31.2 \mu \mathrm{g} \mathrm{ml}{ }^{-1} .{ }^{34}$ Sharma et al. (2016) reported that zinc oxide in nanoscale dimensions damage DNA through lipid peroxidation and oxidative stress in human epidermal cells. They showed that the nanostructured materials can be used as a drug carrier, reducing the non-specific toxicity of strong anticancer drugss ${ }^{35}$ Earlier studies have described that ZnONPs can reduce cell viability due to their potential for cancer treatment. ${ }^{36-38}$ Our findings indicated that the treatment of bacterial cells with CEN-ZnO NPs results in an elevated ROS production. The treatment of $E$. coli and $P$. aeruginosa with CENZnO NPs showed higher ROS production compared to $S$. aureus, which could be explained by the different potentials that are used to change the polarity of the surface for both Gramnegative and Gram-positive bacteria. ${ }^{39,40}$ The production of ROS results in the disruption of the bacterial cell membrane, 


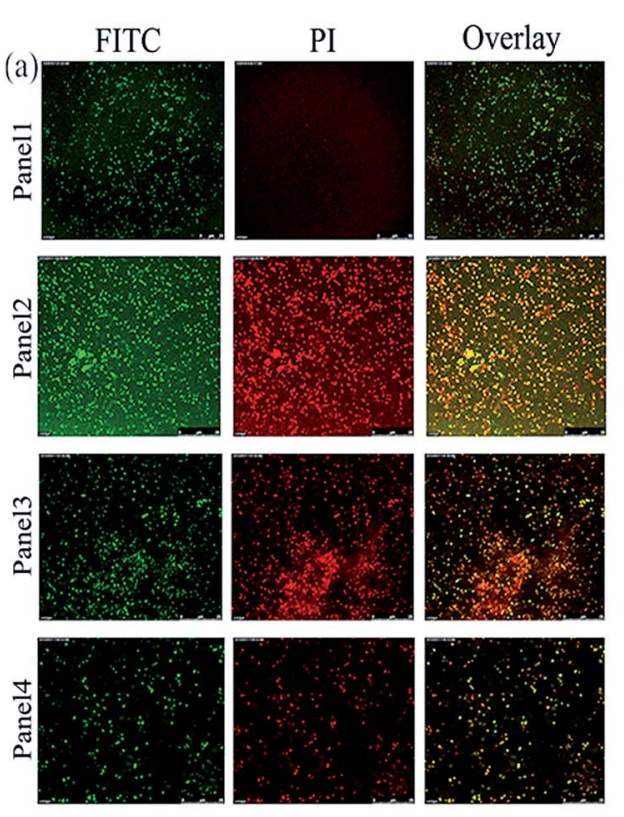

(c)
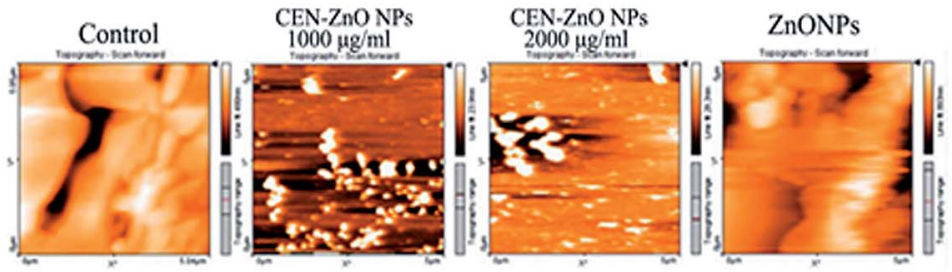

(d)
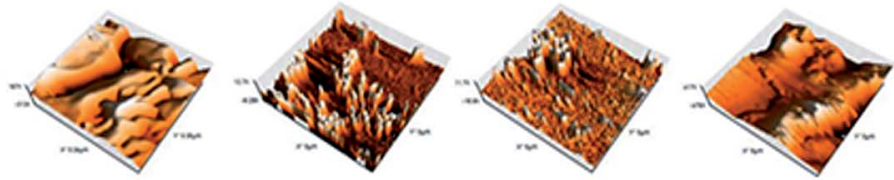

(e)
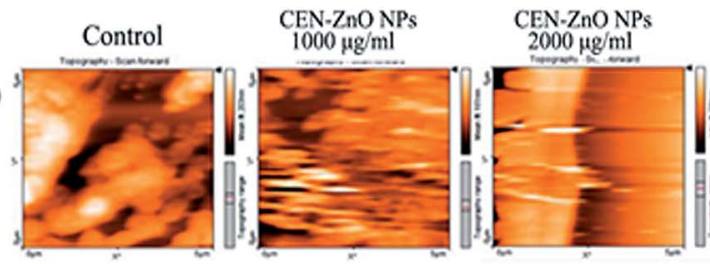

ZnONPs

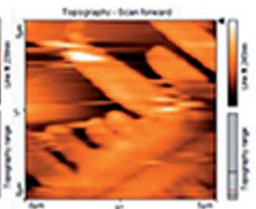

(f)
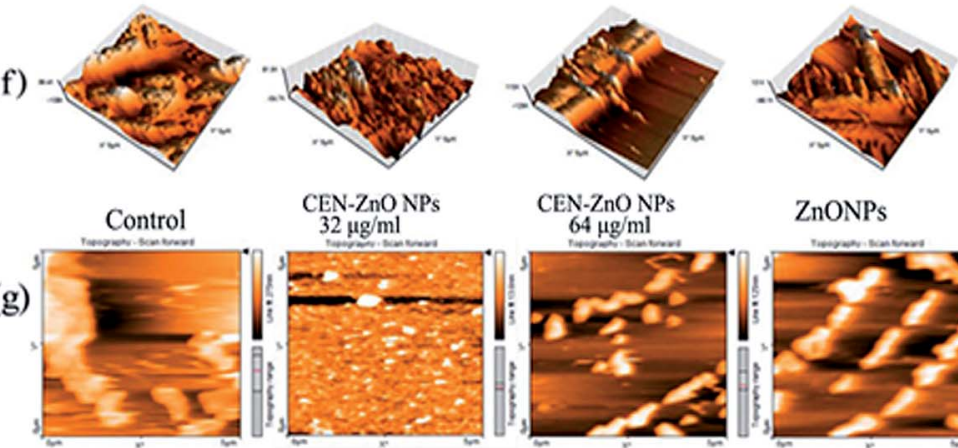

ZnONPs

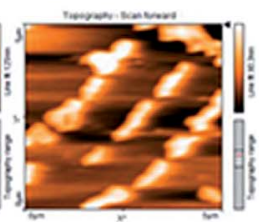

(h)
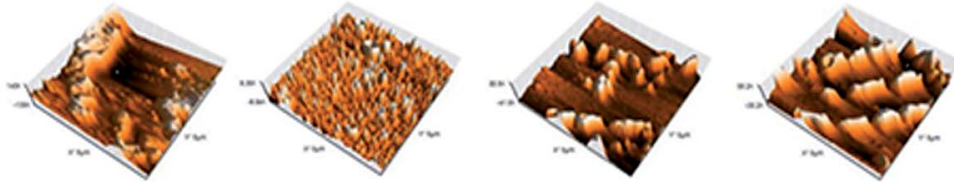

Fig. 9 CLSM micrograph of $P$. aeruginosa (a). S. aureus (b) biofilm. Panel 1 from left to right represent CLSM images of a native biofilm (without CEN-ZnONPs). Panel 2 and panel 3 from left to right represent CLSM images of $P$. aeruginosa (a). S. aureus (b) biofilms treated with CEN-ZnONPs $\left(1500 \mu \mathrm{g} \mathrm{ml}^{-1}\right)$ and $\left(2500 \mu \mathrm{g} \mathrm{ml}^{-1}\right)$ for $P$. aeruginosa and $\left(32 \mu \mathrm{g} \mathrm{ml}^{-1}\right),\left(64 \mu \mathrm{g} \mathrm{ml}^{-1}\right)$ for $S$. aureus. Panel 4 from left to right show CLSM images of $P$. aeruginosa (a). S. aureus (b) biofilm treated with ZnO NPs $\left(6500 \mu \mathrm{g} \mathrm{ml}^{-1}\right)$ for $P$. aeruginosa and $\left(5000 \mu \mathrm{g} \mathrm{ml} \mathrm{l}^{-1}\right)$ for $S$. aureus. AFM images of (c) $E$. coli topography view and (d) 3D view, (e) $P$. aeruginosa topography view, (f) 3D view, (g) S. aureus topography view, and (h) 3D view biofilm. Right images shows native biofilm (no treated with CEN-ZnONPs), whereas, middle images represent AFM images of (c) E. coli, (e) P. aeruginosa and (g) S. aureus biofilms treated with CEN-ZnO NPs. Left images represent AFM images of (c) E. coli, (e) P. aeruginosa and (g) S. aureus biofilm treated with ZnO NPs.

protein denaturation and damage to other macromolecules that ultimately cause cell death. ${ }^{36}$ In a previous report, Xia et al. ${ }^{\mathbf{1 1}}$ compared the mechanism of toxicity of zinc oxide and cerium oxide nanoparticles based on their dissolution and oxidative stress features. They concluded that $\mathrm{ZnO}$-induced toxicity in RAW 264.7 and BEAS-2B cell lines leads to the generation of reactive oxygen species (ROS), oxidant injury, excitation of inflammation, and cell death. In contrast, CeO (2) suppressed
ROS production and induced cellular resistance to an exogenous source of oxidative stress. Guo et al. ${ }^{42}$ also investigated the role of oxidative stress in toxicity and possible contribution of mitochondria in the production of reactive oxygen species (ROS) upon exposure of retinal ganglion cells (RGC-5) to $\mathrm{ZnO}$ nanoparticles. They found that $\mathrm{ZnO}$ nanoparticles decrease the mitochondrial membrane potential, increase the production of ROS, leading to the RGC-5 cell damage and induction of the 

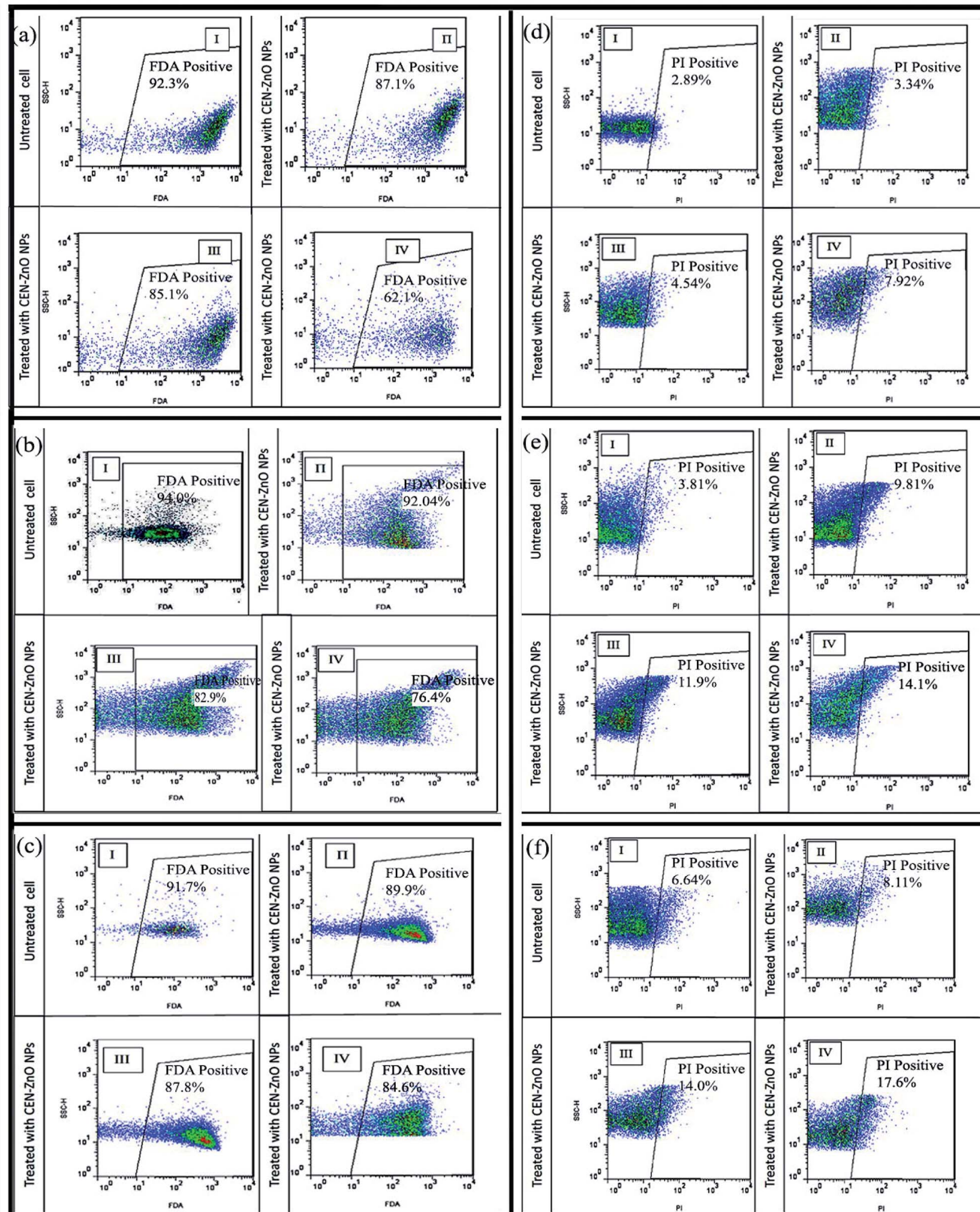

Fig. 10 Flow cytometric analysis of (a) P. aeruginosa, (b) E. coli and (c) S. aureus. The cell viability level as indicated by fluorescein diacetate (FDA) staining (a) and (b) cytograms I: control (untreated sample); II: treated with CEN-ZnO NPs $\left(500 \mu \mathrm{g} \mathrm{ml}^{-1}\right)$, III: $\left(1500 \mu \mathrm{g} \mathrm{ml}^{-1}\right)$ and IV: $\left(2500 \mu \mathrm{g} \mathrm{ml}^{-1}\right)$. (c) Cytograms I: control (untreated sample); II: S. aureus treated with CEN-ZnO NPs $\left(16 \mu \mathrm{g} \mathrm{ml}^{-1}\right)$, III: $\left(32 \mu \mathrm{g} \mathrm{ml} \mathrm{l}^{-1}\right)$ and IV: $\left(64 \mu \mathrm{g} \mathrm{ml} \mathrm{l}^{-1}\right)$. Flow cytometric analysis of (d) P. aeruginosa, (e) E. coli and (f) S. aureus. Membrane internalization staining using prodidium iodide (PI). (a) and (b) Cytograms I: control (untreated sample); II: treated with CEN-ZnO NPs $\left(500 \mu \mathrm{g} \mathrm{ml}^{-1}\right)$, III: (1500 $\mu \mathrm{g} \mathrm{ml}^{-1}$ ) and IV: (2500 $\left.\mu \mathrm{g} \mathrm{ml}{ }^{-1}\right)$. (c) Cytograms I: control (untreated sample); II: S. aureus treated with CEN-ZnO NPs $\left(16 \mu \mathrm{g} \mathrm{ml}^{-1}\right)$, III: $\left(32 \mu \mathrm{g} \mathrm{ml}^{-1}\right)$ and IV: $\left(64 \mu \mathrm{g} \mathrm{ml} \mathrm{I}^{-1}\right)$. 
apoptosis/necrosis. Liu et $a l .{ }^{\mathbf{4 3}}$ investigated the cytotoxicity of two types of ZnO NPs of various sizes and indicate that the reactive oxygen species (ROS) played an essential role in $\mathrm{ZnO}$ NP-induced cytotoxicity, possibly due to the leaching of zinc ions from ZnO NPs. They showed that ZnO NPs induce toxic responses in the human neuroblastoma SHSY5Y cell line in a size-dependent manner, which might be related to their ionshedding ability.

The results obtained from flow cytometry analysis showed that the cell viability decreases with increase in CEN-ZnO NP concentration. Unlike the results obtained here, Bao et al. ${ }^{\mathbf{4 4}}$ used PI dye to analyze the dead fractions of $E$. coli bacterial cells after treatment with $5 \mu \mathrm{g} \mathrm{ml}^{-1}$ and $10 \mu \mathrm{g} \mathrm{ml}{ }^{-1} \mathrm{AgNPs}$ and found that the PI-positive percentages of the bacterial cells were much higher than control groups. However, this increasing PI positive percentage is not correlated to the concentration of the AgNPs, and the highest positive ratio of the bacterial cells detected in the $5 \mu \mathrm{g} \mathrm{ml}^{-1}$ group. ${ }^{44}$ Accurate measurement of nanoparticle entering is important for measuring the physical and chemical properties of nanoparticle uptake into target cells. Also, by increasing the concentration of CEN-ZnO NPs at a fixed time, the penetration rate of nanoparticles into the cell wall of the bacteria increases. It can be speculated that $\mathrm{Zn}^{2+}$ ion release from zinc oxide may result in the transfer of $\mathrm{Zn}^{2+}$ ion into the cell wall, leading to bacteriostatic effects. For example, the interaction between the cell coating components and the $\mathrm{Zn}^{2+}$ ion (from $\mathrm{ZnO}$ ), as reported before, was consistent with the results obtained in our research. ${ }^{45}$ The evidence obtained from confocal laser scanning microscopy (CLSM) analysis showed that while exopolysaccharides with green fluorescence were not detected, many dead cells were observable after treatment of biofilm samples with CEN-ZnO NPs. Since there are water channels (hole) to transport nutrients in biofilms, nanoparticles may penetrate directly through the exopolysaccharide layer. ${ }^{23}$ ZnO nanoparticles (ZNPs) are considered as promising inorganic nanoparticles for use in catalysis, sunscreens, cosmetics, coatings, pigments, and food additives. However, there are ever more concerns for scientists regarding their environmental threats. For example, Li et $a l^{.66}$ studied the uptake and depuration performance of $n \mathrm{ZnO}$ and $\mathrm{Zn}$ ions in a freshwater cladoceran Daphnia magna. They found that the uptake of radiosynthesized $n \mathrm{ZnO}$ by $D$. magna is related to $\mathrm{nZnO}$ concentration. The $n \mathrm{ZnO}$ could enter the body of daphnids and reached the highest level within a short period of time, followed by a quick release. The depuration of $n \mathrm{ZnO}$ was quick and controlled by $n \mathrm{ZnO}$ dissolution. They finally suggested that both dissolved $\mathrm{Zn}$ and nanoparticles had better to be considered essential for studying the toxicology of $n \mathrm{ZnO}$. Rajput et al. ${ }^{47}$ investigated the possible threats caused by toxicity of various NPs on plants and microbial diversity. The exposure of soil to nanoparticles led to a decrease in soil microbial biomass and enzymatic activity, affecting microbial community composition including yeasts, bacteria, fungi, and biological diversity. They concluded that it is expected to divulge whether NPs could compromise crop yield, soil properties, soil organisms, and functional activities of soil.

\section{Conclusion}

The use of cyanobacteria has provided the basis for the development of green nanotechnology, thus reducing the production of unnecessary and impure chemical substances. The present study gives new insight into the use of cyanobacterial cell extracts, as a reducing and capping agent in the synthesis of zinc oxide nanoparticles. Our results showed that the biosynthesized zinc oxide nanoparticles have a favorable biological potential through antibacterial, anti-biofilm, and anticancer activities. The current study has also made significant findings concerning the capacity of the biosynthesized nanoparticles to destroy the lung cancer cell. The number of normal cells was approximately two-fold higher than that of cancer cells upon exposure to CEN-ZnO NPs, at a concentration of $50 \mu \mathrm{g} \mathrm{ml}{ }^{-1}$. In addition to anti-cancer activity, the CEN-ZnO NPs was able to eliminate 24 hour-old biofilms, up to 80 to $90 \%$, in tested bacterial strains.

Altogether, zinc oxide nanoparticles synthesized using the cyanobacterium Nostoc sp. EA03 can be a good candidate for cancer treatment as well as a favorable alternative to common antibiotics for controlling microbial pathogens.

\section{Conflicts of interest}

There are no conflict to declare.

\section{Acknowledgements}

This work was financially supported by National Institute of Genetic Engineering and Biotechnology (NIGEB), affiliated to Iran's Ministry of Science, Research \& Technology.

\section{References}

1 S. Tabrez, J. Musarrat and A. A. Al Khedhairy, Countering drug resistance, infectious diseases, and sepsis using metal and metal oxides nanoparticles, Colloids Surf., B, 2016, 146, 70-83.

2 T. T. Sungkaworn, W. Nalakarn, P. Triampo, D. Tang, Y. Lenbury and P. Picha, The effects of TiO2 nanoparticles on tumor cell colonies: fractal dimension and morphological properties, Int. J. Biomed. Sci., 2007, 2, 62-67.

3 I. O. Sosa, C. Noguez and R. G. Barrera, Optical properties of metal nanoparticles with arbitrary shapes, J. Phys. Chem. B, 2003, 107, 6269-6275.

4 A. Pugazhendhi, R. Prabhu, K. Muruganantham, R. Shanmuganathan and S. Natarajan, Anticancer, antimicrobial and photocatalytic activities of green synthesized magnesium oxide nanoparticles (MgONPs) using aqueous extract of Sargassum wightii, J. Photochem. Photobiol. B Biol., 2019, 190, 86-97.

5 S. Ahmed, A. Ahmad, B. L. Swami and S. Ikram, A review on plants extract mediated synthesis of silver nanoparticles for antimicrobial applications: a green expertise, J. Adv. Res., 2015, 7, 17-28. 
6 G. Patrinoiu, J. M. Calderón-Moreno, C. M. Chifiriuc, C. Saviuc, R. Birjega and O. Carp, Tunable ZnO spheres with high anti-biofilm and antibacterial activity via a simple green hydrothermal route, J. Colloid Interface Sci., 2016, 462, 64-74.

7 M. Shah, D. Fawcett, S. Sharma, S. K. Tripathy and G. E. Poinern, Green synthesis of metallic nanoparticles via biological entities, Materials, 2015, 8, 7278-7308.

8 H. F. Khalid, B. Tehseen, Y. Sarwar, S. Z. Hussain, W. S. Khan, Z. A. Raza, S. Z. Bajwa, A. G. Kanaras, I. Hussain and A. Rehman, Biosurfactant coated silver and iron oxide nanoparticles with enhanced anti-biofilm and anti-adhesive properties, J. Hazard Mater., 2019, 364, 441448.

9 R. P. Rastogi and R. P. Sinah, Biotechnological and industrial significance of cyanobacterial secondary metabolites, Biotechnol. Adv., 2009, 27, 521-539.

10 R. Brayner, H. Barberousse, M. Hemadi, C. Djedjat, C. Yéprémian, T. Coradin, J. Livage, F. Fiévet and A. Couté, Cyanobacteria as bioreactors for the synthesis of $\mathrm{Au}, \mathrm{Ag}$, $\mathrm{Pd}$, and Pt nanoparticles via an enzyme-mediated route, $J$. Nanosci. Nanotechnol., 2007, 7(8), 2696-2708.

11 K. Jiri, Coccoid and colonial cyanobacteria, Freshwater algae of North America, Ecology and Classification, 2003, pp. 59116.

12 I. Rago, C. R. Chandraiahgari, M. P. Bracciale, G. D. Bellis, E. Cestelli, M. C. Zanni, D. Sali, A. Broggi, C. Palleschi, M. Alessandra and D. S. Uccelletti, Zinc oxide microrods and nanorods: different antibacterial activity and their mode of action against Gram-positive bacteria, RSC Adv., 2014, 4, 56031-56040.

13 S. Gunalan, R. Sivaraj and V. Rajendran, Green synthesis of $\mathrm{ZnO}$ nanoparticles against bacterial and fungal pathogens, Prog. Nat. Sci.: Mater. Int., 2012, 22, 693-700.

14 F. M. Morsy, N. A. Nafady, M. H. Abd-Alla and D. A. El-Hady, Green synthesis of silver nanoparticles by water soluble fraction of the extracellular polysaccharides/matrix of the cyanobacterium Nostoc commune and its application as a potent fungal surface sterilizing agent of seed crops, Univers. J. Microbiol. Res., 2012, 2, 36-43.

15 K. Jiri, and J. R. Johansen, Fresh water Algae of North America, Ecology and classification, Academic Press: Elsvier Science (USA), 2003, pp. 135-235.

16 E. Valerio, L. Chambel, S. Paulino, N. Faria, P. Pereira and R. Tenreiro, Molecular identification, typing and traceability of cyanobacteria from freshwater reservoirs, Microbiology, 2009, 155, 642-656.

17 S. F. Altschul, W. Gish, W. Miller, E. W. Myers and D. J. Lipman, Basic local alignment search tool, J. Mol. Biol., 1990, 215, 403-410.

18 N. Saitou and M. Nei, The neighbor-joining method: a new method for reconstructing phylogenetic trees, Mol. Biol. Evol., 1987, 4, 406-425.

19 Y. H. Diana and B. Parthipan, Compounds Identification from Hypersaline Oscillatoria Salina Using GC-MS analysis, Int. J. Res. Stud. Biosci., 2015, 3, 6-10.
20 F. R. Kockerill et al., Clinical and Laboratory Standards Institute, Methods for dilution antimicrobial susceptibility tests for bacteria that grow aerobically, Approved Standard, 9th edn, 2012, vol. 29.

21 P. Sabaeifard, A. Abdi-Ali, M. R. Soudi and R. Dinarvand, Optimization of tetrazolium salt assay for Pseudomonas aeruginosa biofilm using microtiter plate method, $J$. Microbiol. Methods, 2014, 105, 134-140.

22 B. Pitts, M. A. Hamilton, N. Zelver and P. S. Stewart, A microtiter-plate screening method for biofilm disinfection and removal, J. Microbiol. Methods, 2003, 54, 269-276.

23 J. A. Banas, K. R. Hazlett and J. E. Mazurkiewicz, An in vitro model for studying the contributions of the Streptococcus mutans glucan-binding protein-A to biofilm structure, Methods Enzymol., 2001, 337, 425-433.

24 M. A. Ansari, H. M. Khan, A. A. Khan, S. S. Cameotra and R. Pal, Antibiofilm efficacy of silver nanoparticles against biofilm of extended spectrum B-lactamase isolates of Escherichia coli and Klebsiella pneumoniae, Appl. Nanosci., 2014, 4, 859-868.

25 C. Jayaseelan, A. A. Rahuman, A. V. Kirthi, S. Marimuthu, T. Santhoshkumar, A. Bagavan, K. Gaurav, L. Karthik and K. V. Rao, Novel microbial route to synthesize $\mathrm{ZnO}$ nanoparticles using Aeromonas hydrophila and their activity against photogenic bacteria and fungi, Spectrochim. Acta A Mol. Biomol. Spectrosc., 2012, 90, 78-84.

26 G. Singh, P. K. Babele, A. Kumar, A. Srivastava, R. P. Sinha and M. B. Tyagi, Synthesis of ZnO nanoparticles using the cell extract of the cyanobacterium, Anabaena strain L31 and its conjugation with UV-B absorbing compound shinorine, J. Photochem. Photobiol., B, 2014, 138, 55-62.

27 M. Premanathan, K. Karthikeyan, K. Jeyasubramanian and G. Manivannan, Selective toxicity of $\mathrm{ZnO}$ nanoparticles toward Gram-positive bacteria and cancer cells by apoptosis through lipid peroxidation, J. Nanomed. Nanotechnol., 2011, 7, 184-192.

28 L. K. Adams, D. Y. Lyon and P. J. J. Alvarez, Comparative ecotoxicity of nanoscale $\mathrm{TiO}_{2}, \mathrm{SiO}_{2}$, and $\mathrm{ZnO}$ water suspensions, Water Res., 2006, 40, 3527-3532.

29 A. Khursheed, D. Sourabh, A. Ameer, A. S. Quaiser, S. Mansour, A. Alkhedhairy and M. Javed, Aloe vera extract functionalized zinc oxide nanoparticles as nanoantibiotics against multi-drug resistant clinical bacterial isolate, $J$. Colloid Interface Sci., 2016, 472, 145-156.

30 L. Zhang, Y. Jiang, Y. Ding, M. Povey and D. York, Investigation into the antibactrial behaviour of suspension of zno nanoparticles (ZnO nanofluids), J. Nanoparticle Res., 2007, 9, 479-489.

31 M. A. Rauf, M. Owais, R. Rajpoot, F. Ahmad, N. Khan and S. Zubair, Biomimetically synthesized zno nanoparticles attain potent antibacterial activity against less susceptible $S$. aureus skin infection in experimental animals, $R S C A d v$, 2017, 7, 36361-36373.

32 A. Sirelkhatim, S. Mahmud, A. Seeni, N. H. M. Kaus, L. Ann, S. K. M. Bakhori, H. Hassan and D. Mohammad, Review on zinc oxide nanoparticles: antibacterial activity and toxicity mechanism, Nano-Micro Lett., 2015, 7, 219-242. 
33 B. Malaikozhundan, B. Vaseeharan, S. Vijayakumar, K. Pandiselvi, M. A. Kalanjiam, K. Murugan and G. Benelli, Biological therapeutics of Pongamia pinnata coated zinc oxide nanoparticles against clinically important pathogenic bacteria, fungi and MCF-7 breast cancer cells, Microb. Pathog., 2017, 104, 268-277.

34 D. Selvakumari, R. Deepa, V. Mahalakshmi, P. Subhashini and N. Lakshminarayan, Anti-cancer activity of zno nanoparticles on MCF7 (breast cancer cell) and A549 (lung cancer cell), ARPN J. Eng. Appl. Sci., 2015, 10, 5418-5421.

35 H. Sharma, K. Kumar, C. Choudhary, P. K. Mishra and B. Vaidya, Development and characterization of metal oxide nanoparticles for the delivery of anticancer drug, Artif. Cells, Nanomed., Biotechnol., 2016, 44, 672-679.

36 A. Kumar, M. Najafzadeh, B. K. Jacob, A. Dhawan and D. Anderson, Zinc oxide nanoparticles affect the expression of p53, Ras p21 and JNKs: an ex vivo/in vitro exposure study in respiratory disease patients, Mutagenesis, 2015, 30, 237-245.

37 K. Meyer, P. Rajanahali, M. Ahamed, J. J. Rowe and Y. Hong, $\mathrm{ZnO}$ nanoparticles induce apoptosis in human dermal fibroblasts via p53 and p38 pathways, Toxicol. in Vitro, 2011, 28, 1721-1726.

38 A. Punnoose, K. Dodge, J. W. Rasmussen, J. Chess, D. Wingett and C. Anders, Cytotoxicity of $\mathrm{ZnO}$ nanoparticles can be tailored by modifying their surface structure: A green chemistry approach for safer nanomaterials, ACS Sustain. Chem. Eng., 2014, 2, 1666-1673.

39 A. F. Tavares, M. Teixeira, C. C. Romao, J. D. Seixas, L. S. Nobre and L. M. Saraiva, Reactive oxygen species mediate bactericidal killing eliciated by carbon monoxidereleasing molecules, J. Biol. Chem., 2011, 286, 26708-26717.

40 H. L. Su, C. C. Chou, D. L. Hung, I. C. Pao, J. H. Lin, F. L. Huang, R. X. Dong and J. J. Lin, The disruption of bacterial membrane integrity through ROS generation induced by nano hybrids of silver and clay, Biomaterials, 2009, 30, 5979-5987.

41 T. Xia, M. Kovochich, M. Liong, L. Mädler, B. Gilbert, H. Shi, J. I. Yeh, J. I. Zink and A. E. Nel, Comparison of the mechanism of toxicity of zinc oxide and cerium oxide nanoparticles based on dissolution and oxidative stress properties, ACS Nano, 2008, 2, 2121-2134.

42 D. Guo, H. Bi, B. Liu, Q. Wu, D. Wang and Y. Cui, Reactive oxygen species-induced cytotoxic effects of zinc oxide nanoparticles in rat retinal ganglion cells, Toxicol. In Vitro, 2013, 27, 731-738.

43 J. Liu, Y. Kang, S. Yin, B. Song, L. Wei, L. Chen and L. Shao, Zinc oxide nanoparticles induce toxic responses in human neuroblastoma SHSY5Y cells in a size-dependent manner, Int. J. Nanomed., 2017, 12, 8085-8099.

44 H. Bao, X. Yu, C. Xu, X. Li, Z. Li, D. Wei and Y. Liu, New toxicity mechanism of silver nanoparticles: promoting apoptosis and inhibiting proliferation, PLoS One, 2015, 10(13), e0122535.

45 Y. Zhang, L. Wang, X. Xu, F. Li and Q. Wu, Combined systems of different antibiotics with nano-CuO against Escherichia coli and the mechanisms involved, Nanomedicine, 2018, 13, 339-351.

46 W. M. Li and W. X. Wang, Distinct biokinetic behavior of ZnO nanoparticles in Daphnia magna quantified by synthesizing ${ }^{65} \mathrm{Zn}$ tracer, Water Res., 2013, 47(2), 895-902.

47 V. D. Rajput, T. Minkina, S. N. Sushkova, V. Tsitsuashvili, S. S. Mandzhieva, A. V. Gorovtsov, D. Nevidomskyaya and N. Gromakova, Effect of nanoparticles on crops and soil microbial communities, J. Soils Sediments, 2018, 18, 21792187. 